\title{
HRVATSKI TISAK I OPĆINSKI IZBORI U TINJANU NA POČETKU XX. STOLJEĆA
}

Dr. sc. Željko Klaić

Gospodarska škola Varaždin

Božene Plazzeriano 4, HR - 42000 Varaždin

zeljko.klaic.vz@gmail.com
UDK 352(497.5Tinjan)

Izvorni znanstveni članak

Primljeno: 7. 12. 2015.

Prihvaćeno: 8. 6. 2016.

DOI: http://doi.org/10.21857/mzvkptxe19

Općina Tinjan u Markgrofoviji Istri početkom XX. stoljeća jedna je od 54 mjesne, odnosno područne općine. Hrvatsko-slovenska narodna stranka na kraju XIX. stoljeća učvrstila je svoje pozicije u tinjanskoj općini. Stranka je na općinskim izborima pobjedivala i prije 1887. U kontinuitetu odnosi izborne pobjede od te godine. Pobijedila je u sva tri izborna tijela, ali-zbog talijanskog utoka - novo zastupstvo konstituiralo se tek 8. kolovoza 1888. Za načelnika će biti izabran Šime Defar. Narodna stranka pobijedila je i na izborima 1891. u sva tri izborna tijela te 1895. i 1899. Za načelnika je svaki put bio izabran vođa hrvatskih narodnjaka u tinjanskoj općini Šime Defar. Bio je trgovac $i$ posjednik, povezan s ostalim hrvatskim narodnjacima središnje Istre, ali i šire. Godine 1903. u tinjanskoj općini dolazi do preokreta - Defarova stranka gubi izbore - a za načelnika je i tada i ponovno 1907. izabran Venceslav Križmanić. Općenito, hrvatski autori Defarov poraz i poraz njegove stranke obrazlažu talijanskom propagandom, zaduženošću seljaka kod talijanskih trgovaca i posjednika, nedovoljno izgrađenom nacionalnom svijesti te sukobima $u$ hrvatskim redovima.

Ključne riječi: Šime Defar; Venceslav Križmanić; Ivan Krstić; Naša sloga; Narodni list; Obzor; općinski izbori u Tinjanu; istarski narodnjaci; talijanski liberali.

Kurijalni izborni sustav pogodovao je bogatijim, posjedničkim i građanskim slojevima, a tu su se talijanski nacionalni liberali kao predstavnici tih slojeva u Istri nalazili u prednosti. ${ }^{1}$ Izborni se sustav zasnivao na ekonomski snažnijima i poli-

$\overline{1}$ Istarski su Talijani utemeljili svoju političku organizaciju 1884. u Pazinu. Talijansko političko društvo predstavljat će u Istri Talijansku nacionalno-liberalnu stranku (Partito Liberale Nazionale, odnosno Partito Liberale Italiano). U Pravilima Istarskoga političkog društva naveden je kao dan donošenja datum održavanja osnivačke skupštine u Pazinu. Namjesništvo u Trstu na temelju zakona od 15. studenoga 1867. potvrdilo je društvena pravila 29. veljače 1884. Statuto dell'associazione politica 'Società Politica Istriana', Parenzo, 1884., 3-10; Usput: Giovanni D'Alessio, „Nacionalna društva i politička borba u Pazinu krajem habsburške vladavine”, Hrvatska čitao- 
tička je zastupljenost trebala razmjerno odgovarati prinosu koji se davao državi. ${ }^{2}$ Izbornici su bili popisani i podijeljeni po kurijama, a pritom se pridavala važnost posjedničkim i građanskim slojevima. Istarski je sabor imao kuriju veleposjeda, trgovačko-obrtničku komoru, kuriju gradova, kuriju seoskih općina te tri virilna člana (istarske biskupe). Hrvati i Slovenci, koji su većinom živjeli na selu, bili su brojniji u odnosu na Talijane, ali ekonomski slabiji, tako da je sustavom izbornih kurija talijanskim liberalima omogućena odlučujuća uloga u autonomnim političkim, ali i gospodarskim i kulturnim tijelima. Hrvati i Slovenci nisu mogli uzimati u obzir kuriju veleposjeda i najveći dio gradske kurije. Talijanski su liberali pod pritiskom bečke vlade, kao i hrvatski narodnjaci, ${ }^{3}$ u ožujku 1908. prihvatili djelomičnu demokratizaciju izbornoga sustava, a novom je izbornom geometrijom talijanskim liberalima u Saboru i dalje bila osigurana prevlast. Od hrvatskih nacionalnih prvaka i zastupnika sporazum nisu odobrili Vjekoslav Spinčić i Matko Mandić, a od talijanskih liberala odvjetnik Felice Bennati. Kao predsjednik Talijanske liberalne stranke, nezadovoljan politikom carsko-kraljevske vlade, on podnosi ostavku na zastupničko mjesto i ne sudjeluje u Saboru pri donošenju novoga zemaljskog izbornog reda. ${ }^{4}$

nica u Pazinu, Pazin u drugoj polovini 19. i početkom 20. stoljeća, zbornik radova, Pazin 1999., 83, 88-89.

2 U vrijeme diskusija pokrenutih u bečkom parlamentu oko prijedloga novoga izbornog zakona za Carevinsko vijeće, predsjednik se vlade Paul Gautsch 28. studenoga 1905. ogradio od prijedloga da se podjela mandata temelji na postotnom udjelu stanovništva smatrajući da treba voditi računa o povijesnom položaju pokrajina, o velikim razlikama što postoje među pripadnicima pojedinih narodnosti u pogledu njihova ekonomskog i kulturnog razvitka te o važnosti koju one imaju u državi i za državu. Dragovan Šepić, „Nacionalna borba u Istri i izbori za Carevinsko vijeće 1907.", Hrvatski narodni preporod u Dalmaciji i Istri, Zagreb, 1969., 412.

Vidi o narodnjacima i narodnjaštvu u Istri: Božo Milanović, Hrvatski narodni preporod u Istri, I, Pazin, 1967., 53-138, 181-272, 280-321; isti, Hrvatski narodni preporod u Istri, II, Pazin, 1973., 13-423, 435-445, 455-461; Josip Percan, Obzori istarskog narodnjaštva, I, Pula - Rijeka, 1986., 39-412; isti, Obzori istarskog narodnjaštva, II, Pula - Rijeka, 1986., 9-350; isti, Obzori istarskog narodnjaštva, III, Pula - Rijeka, 1989., 7-330; Zvane Črnja, Obećana zemlja, Pula, 1978., 56; isti, „Predgovor“, u: J. Percan, Obzori istarskog narodnjaštva, I, 7-13; Josip Bratulić, „Narodnjaci“, Istarska enciklopedija, ur. Miroslav Bertoša i Robert Matijašić, Zagreb, 2005., 525-526.

4 Novim izbornim zakonom Hrvati i Slovenci mogli su povećati broj zastupnika u Saboru na 19 od ukupno 47. Prije ih je bilo 9. Među tih 47 ubrojena su i tri istarska biskupa kao virilisti. Po kurijama je bilo predviđeno 5 predstavnika velikoga zemljišnog posjeda, 2 predstavnika trgovačko-obrtničke komore, 14 predstavnika gradova, trgovišta i obrtnih mjesta, 15 predstavnika seoskih općina i 8 predstavnika općega razreda. Od 19 hrvatsko-slovenskih predstavnika, 3 su se odnosila na kuriju gradova, 12 na kuriju seoskih općina i 4 na kuriju općega razreda, u kojoj su imali pravo glasa muškarci s navršene 24 godine. Zemaljski odbor, kao upravni i izvršni organ zemaljskoga zastupstva, sastojat će se od 5 prisjednika: jednoga će birati veliki zemljišni posjed, dvojicu će birati gradovi, trgovišta, obrtna mjesta te trgovačko-obrtnička komora, a dvojicu će birati seoske izvanjske općine. Od 5 prisjednika za Hrvate i Slovence predviđena su njih 2, koji se biraju u seoskim općinama. Određena su bila i jamstva za manjinu, zbog mogućega preglasavanja. Za donošenje odluke od određene važnosti u Saboru moraju biti prisutna 32 člana, od njih mora biti najmanje 7 slavenskih predstavnika kada su, kao što je bilo uobičajeno, nedostajali istarski biskupi. U Zemaljskom odboru za pravovaljanost odluke trebala su, uz zemaljskoga kapetana ili njegova zamjenika, biti prisutna najmanje 3 člana, od kojih je 1 morao biti od predstavnika gradova, dakle Talijan, a drugi od pred- 
Bez obzira na sporazum iz 1908., ${ }^{5}$ rad u Saboru nije se mogao odvijati zbog čestih suprotstavljanja i prekida rada. Austrijski imovinsko-dohodovni i kurijalni izborni sustav omogućavao je i talijansku većinu u gotovo svim istarskim općinama. ${ }^{6}$

Početkom XX. stoljeća od 54 mjesne općine u Istarskoj markgrofoviji 22 su se nalazile u rukama Hrvatsko-slovenske narodne stranke (u skraćenom obliku Narodna stranka). ${ }^{7}$ Prve mjesne općine koje prelaze u ruke istarskih narodnjaka osamdesetih

stavnika seoskih općina, dakle Slaven. Talijanski povjesničar Bernardo Benussi promatra garancije za manjinu kao ustupak carsko-kraljevske vlade Slavenima, koji su uvijek mogli blokirati budući rad Sabora, a svojim privilegiranim glasom služiti se kao sredstvom ucjene. Dragovan Šepić, „Politika 'narodnog mira' u Istri 1908.-1913.", Anali Jadranskog instituta, III, 1961., 69-95; Bernardo Benussi, L'Istria nei suoi due millenni di storia, Collana degli Atti 14, Rovigno, 1997., 599-600; isti, Povijest Pule u svjetlu municipalnih ustanova do 1918. godine, Pula, 2002., 618-622.

Na izborima za Istarski sabor u listopadu i studenom 1908., na temelju novoga izbornog zakona, u kuriji velikoga zemljišnog posjeda izabrano je 5 talijanskih liberala; u kuriji gradova 11 talijanskih liberala, 1 talijanski socijalist i 2 slavenska narodnjaka; u trgovačko-obrtničkoj komori 2 talijanska liberala; u kuriji seoskih općina 3 talijanska liberala, 11 slavenskih narodnjaka; u općoj kuriji 3 talijanska liberala, 1 talijanski socijalist, 4 slavenska narodnjaka. Matko Mandić izabran je dvostruko, u Koparštini i u Kotaru Volosko-Podgrad. Odrekao se mandata u kotaru Volosko-Podgrad i umjesto njega mandat je dobio Ivan Pošćić. Tako su u Saboru bila 24 talijanska liberala, 2 talijanska socijalista i 18 slavenskih narodnjaka. Izbor Carla Franka u trećem izbornom kotaru grada Pule nije odgovarao sporazumu i to je dalo povoda hrvatskim kritičarima novoga zemaljskog izbornog zakona, koji su optuživali nacionalno vodstvo što se uopće pregovaralo s talijanskim liberalima koji ne poštuju dogovor. Nakon smrti C. Franka u Puli je krajem rujna 1912. u trećem izbornom kotaru izabran narodnjak Josip Stihović. Paolo Ziller, „Sistema elettorale e rappresentanza politica in Istria nel periodo costituzionale asburgico (1861-1918)“', Atti del Centro di ricerche storiche, XXIV, 1994., 545-546; B. Milanović, Hrvatski narodni preporod u Istri, II, 144-159.

6 Izbornici su u općini bili podijeljeni prema pravilu u 3 izborna tijela, a na 2 tijela tamo gdje je bio malen broj izbornika, o čemu je odlučivala kotarska vlast. Svako od 3 tijela izabiralo je jednak broj zastupnika. No, u tijelima nije bio jednak broj izbornika. U prvo izborno tijelo spadali su svi počasni članovi općine i one osobe koje su imale aktivno izborno pravo bez obzira na to jesu li plaćale izravni porez. $U$ to tijelo spadale su i one osobe koje su davale najveći iznos poreza. Naime, osobe koje su plaćale izravni porez u općinama stavljene su na popis određenim redoslijedom - prvi na popisu bio je onaj koji je plaćao najviši iznos poreza. Ukupan iznos poreza podijelio se na 3 dijela, pa su oni kojima su iznosi ulazili u prvu trećinu poreza spadali u prvo izborno tijelo, druga trećina u drugo tijelo i treća trećina u treće izborno tijelo. Očito je u prvo izborno tijelo spadalo najmanje izbornika i čitav je općinski izborni zakon išao u prilog onima koji su plaćali najviše poreze. Prva 2 tijela mogla su izabirati većinu općinskih zastupnika, ali oba ta tijela nisu imala ukupno toliko birača koliko je imalo samo treće izborno tijelo. Zbirka zakona potrebnih u javnom životu u Istri i druguda. Preveo i priredio Ivan Zuccon, prisjednik Zemaljskog odbora, Knjiga prva, Pula, 1911., 17-56, 61-75; Vjekoslav Bratulić, „Zapisnici sjednica 'Hrvatsko-slovenskog kluba' zastupnika u Istarskom saboru (1884-1901)", Vjesnik Historijskog arhiva u Rijeci i Pazinu, XI-XII, 1966.-1967., 123-131; Ivan Beuc, Istarske studije. Osnovni nacionalni problemi istarskih Hrvata i Slovenaca u drugoj polovini XIX i početkom XX stoljeća (dalje: Istarske studije), Zagreb, 1975., 43-141, 201-202, 273; Angelo Ara, Ricerche sugli austroitaliani e l'ultima Austria, Roma 1974., 247-328; Salvator Žitko, „Slovensko-hrvaški politični odnosi v Istri v času ustavne dobe 1861-1914”, Annales, 12, 1, 2002., 32-50; D. Šepić, „Politika 'narodnog mira' u Istri 1908.-1913.", 69-123; B. Benussi, Povijest Pule u svjetlu municipalnih ustanova do 1918. godine, 618-622, 671; P. Ziller, 533-552.

Stjepan Radić, ,'Neoprostiv grieh"“, Novi list, Rieka, 17. travnja 1904. 
godina XIX. stoljeća bile su Kastav, Pazin, Buzet, Žminj, Tinjan i Vrbnik. ${ }^{8}$ Slovenski narodnjaci u isto vrijeme drže pozicije u općinama Dekani, Dolina, Pomjan, Podgrad, Materija i Jelšane. ${ }^{9}$

Na prijelomu XIX. i XX. stoljeća nacionalni pokret Hrvata i Slovenaca u Istri ulazi u period stagnacije. Pokazatelj su rezultati zemaljskih i državnih izbora.

U izborima za Sabor istarski narodnjaci 1889. prvi put dobivaju devet zastupnika, kao i na izborima 1895. te na izborima održanima krajem 1901. godine. Broj od devet zastupnika ostat će sve do zemaljske izborne reforme 1908. Tako je na prijelomu stoljeća u zemaljskom saboru Narodna stranka čuvala pozicije koje je zadobila u kuriji seoskih općina kotara Kopar, Pazin, Volosko i Lošinj, i to ostvarenih osam mandata. Ne ostvaruje izborne uspjehe u seoskim općinama kotara Poreča i Pule. Jedan mandat Narodna stranka ostvarila je u kuriji gradova u istočnoj Istri. Daleko više na zastoj u razvoju pokreta ukazuju rezultati izbora za bečki parlament. $\mathrm{Na}$ izborima za Carevinsko vijeće 1891., Hrvati i Slovenci dobivaju dva predstavnika, Matka Laginju i Vjekoslava Spinčića kao zastupnike kurije seoskih općina. Izjednačili su se tako s Talijanima, koji su izabrali svoja dva predstavnika u kuriji gradova, trgovačko-obrtničkoj komori i kuriji veleposjeda. Laginja je izabran u seoskim općinama zapadne Istre, a Spinčić u onima istočne Istre. Prvi put Hrvate i Slovence u bečkom parlamentu zastupaju dva predstavnika od ukupno četiri, koliko ih je Istru zastupalo u Carevinskom vijeću. Dvoje od njih bili su talijanski nacionalni liberali, Lodovico Rizzi i Matteo Bartoli. ${ }^{10}$

Kad je reformom 1896. uvedena peta generalna kurija u izborima za bečki parlament, u kojoj su sveopće izborno pravo imali muškarci s navršene 24 godine, provedeni izbori početkom 1897. talijanskim nacionalnim liberalima donose tri mandata, a hrvatsko-slovenskim narodnjacima dva mandata. U petoj kuriji Matka Laginju pobijedio je predstavnik talijanskih liberala Matteo Bartoli. U kuriji seoskih općina

8 Božo Milanović, “"Nekadašnje istarske općine“, Istarska Danica 1977., Pazin, 1976., 94-98.

Janez Kramar, Narodna prebuja istrskih Slovencev, Koper, 1991., 74-88.

Matko Laginja pobijedio je nakon ponovljenih izbora u listopadu 1891. Naime, s izborima u ožujku talijanska je strana pretrpjela veliku blamažu i javnu kompromitaciju u krivotvorenju i namještanju izbornih rezultata u vanjskim općinama sudskih kotara Poreč, Motovun, Buje, Kopar, Piran, Buzet, Vodnjan, Pula i Rovinj, gdje su se kandidirali Matko Laginja i Tommaso Vergottini, što je nedvojbeno utvrdio legitimacijski odbor Carevinskog vijeća. Nakon što je već bio prisegnuo, a pod pritiskom je javnosti i usvojenom žalbom Verifikacijskoga odbora Vergottini bio prisiljen podnijeti ostavku na mjesto zastupnika. Na ponovljenim izborima u listopadu Laginjin protukandidat bio je Benedetto Polesini. Tada su fiducijari seoskih općina koparskoga kotara za Laginju dali 53 glasa. Važnu ulogu odigrali su i glasovi hrvatskih seljaka iz okolice Oprtlja, Kanfanara i Savičente, koji su na izborima u tim mjestima osigurali pobjedu hrvatskih pouzdanika, odnosno fiducijara. Sveukupno Laginja dobiva 108 glasova, a Polesini 104 glasa. Bila je to pobjeda koja je bitno utjecala na buđenje nacionalne svijesti istarskih Hrvata i Slovenaca. Vjekoslav Bratulić, „Hrvatski zastupnici u Istarskom saboru i Carevinskom vijeću devedesetih godina XIX. stoljeća i suradnja južnoslavenskih naroda", Jadranski zbornik, III, 1958., 149-157; Nevio Šetić, O povezanosti Istre s ostalim hrvatskim zemljama: Naša Sloga 1870.1915., Zagreb, 2005., 95-96. 
zapadne Istre pobjeđuje Matko Laginja, a u kuriji seoskih općina istočne Istre Vjekoslav Spinčić. U kuriji gradova i trgovačko-obrtničkoj komori izabran je Lodovico Rizzi, a u kuriji veleposjeda Pier Antonio Gambini. ${ }^{11}$

Izbori održani početkom 1901. bili su porazni za Hrvatsko-slovensku narodnu stranku. Talijanski nacionalni liberali osvojili su četiri mjesta, a slavenski narodnjaci jedno mjesto u Carevinskom vijeću u Beču. Od 4.191 glasa danog kandidatima, talijanski su liberali dobili 3.118 glasova, a narodnjaci 1.073 glasa. Lodovico Rizzi, pulski gradonačelnik, izabran je u okrugu zapadnih seoskih općina sa 117 glasova, protiv Matka Mandića, koji je osvojio 96 glasova. Narodnjaci su tako nakon 1891. i nakon 1897. izgubili mandat u kuriji seoskih općina zapadne Istre. U kuriji seoskih općina istočne Istre mandat je osvojio Vjekoslav Spinčić. Felice Bennati osvojio je mandat $\mathrm{u}$ petoj generalnoj kuriji s 315 glasova, protiv Matka Laginje, koji je osvojio 285 glasova. U kuriji gradova i trgovačko-obrtničkoj komori izabran je Matteo Bartoli. Benedetto Polesini izabran je u kuriji velikog zemljišnog posjeda. Na tim izborima bilo je primjera da su za talijanske liberalne kandidate dolazili glasovi od hrvatskih i slovenskih izbornika. ${ }^{12}$

Izborni rezultati 1897. i 1901. ukazuju na slabljenje hrvatskih i slovenskih pozicija u Istri i Trstu, a jačanje pozicija talijanskih liberala. Treba ipak konstatirati da se slovenski izborni neuspjeh u trećem izbornom kotaru u Trstu 1897. i 1901. ponajprije dogodio zbog prekida apstinencije talijanskih građanskih liberala, ali je nakon izbora jačao i talijanski iredentizam, koji će u Kraljevini Italiji početkom stoljeća stjecati sve veću afirmaciju, kao što će njegov utjecaj prodirati i među Talijane u AustroUgarskoj. Političko društvo Edinost iz Trsta sagledavalo je izlaz iz kriznog stanja ponajprije u Sjedinjenoj Sloveniji, ${ }^{13}$ a istarski narodnjaci kretali su prema utemeljenju vlastite političke organizacije, koja je i utemeljena 1902. sa sjedištem u Pazinu Političkog društva za Hrvate i Slovence u Istri. ${ }^{14}$ Za predsjednika Političkog društva

$\overline{11}$ Vjekoslav Bratulić, „O suradnji južnoslavenskih zastupnika Carevinskog vijeća (1894-1900) i o problemu nacionalnosti u Austriji”, Anali Jadranskog instituta, III, 1961., 17-26; B. Benussi, L'Istria nei suoi due millenni di storia, 581-582; isti, Povijest Pule u svjetlu municipalnih ustanova do 1918. godine, 587, 594; J. Kramar, 49-57, 157; P. Ziller, 539-540, 544.

12

Na istome mjestu.

Dragovan Šepić, „Talijanski iredentizam na Jadranu”, Časopis za suvremenu povijest, 7, 1, 1975., 10-14; Vasilij Melik, „Slovenci v državnem zboru 1893-1904”, Zgodovinski časopis, 33, 1, 1979., 53-54; S. Žitko, 45.

Političko društvo Edinost iz Trsta počelo je djelovati u drugoj polovini 1874. Društvo je 1878. proširilo svoju aktivnost na čitavo Austrijsko primorje, koje je bilo pod upravom Namjesništva u Trstu. Edinost je tako proširila aktivnost i na Istru. „Slogaštvo" istarskoga nacionalnog pokreta pogotovo je došlo do izražaja u zajedničkom i organiziranom radu političara, odnosno istarskih poslanika u Hrvatsko-slovenskom klubu zastupnika u Istarskom saboru, utemeljenom 10. lipnja 1884. Bila je to ujedno i godina kad nastaje Hrvatsko-slovenska narodna stranka. Stranka nije postojala kao čvrsta politička organizacija već izborna koalicija hrvatskih i slovenskih političara. Pravi se politički rad do 1902., kad je ustanovljeno Političko društvo za Hrvate i Slovence u Istri sa sjedištem u Pazinu, odvijao kroz Političko društvo Edinost u Trstu. Program političkih predstavnika istarskih Hrvata 
izabran je Vjekoslav Spinčić, Dinko Trinajstić izabran je za potpredsjednika, Gjuro Červar za tajnika, a Šime Kurelić za blagajnika. ${ }^{15}$

Poteškoće u razvoju nacionalnoga pokreta na prijelomu stoljeća očitovale su se i u gospodarskim odnosima. Naime, problem je bio kako spasiti seljaštvo kao najbrojniji sloj hrvatskog i slovenskog stanovništva od propadanja, kako ga osloboditi zaduženosti. Voditelji nacionalnoga pokreta provodili su na kraju XIX. i početkom XX. stoljeća akciju ustanovljavanja zadružnih organizacija, i to na temelju austrijskoga zadružnog zakona od 9. travnja 1873. Voditelji pokreta pristupit će organiziranju kreditnih zadruga, tzv. posujilnica, a zatim i gospodarsko-potrošačkih zadruga. Godine 1891. utemeljena Istarska posujilnica u Puli, koju je vodio Matko Laginja, postat će najvećim hrvatskim novčanim zavodom u Istri, a njezina podružnica u Pazinu, utemeljena 1895., započinje svoj rad u odvjetničkoj pisarni Dinka Trinajstića, budućega voditelja akcije utemeljenja Političkog društva. Istarska posujilnica u Puli, sa svojom podružnicom u Pazinu koja je djelovala s ograničenim jamstvom, bila je aktivna u smislu potpomaganja i uspostave manjih kreditnih zadruga Raiffeisenova tipa koje su djelovale na osnovi neograničenog jamstva. Zadruge su stvarale uvjete gospodarske neovisnosti seljaka, a zatim su i omogućile izražavanje njihove vlastite volje kod raznih izbora. Premda je pred Svjetski rat bila izgrađena čitava mreža zadružnih organizacija, krizu su seljaci - pogotovo najsiromašniji - sitni posjednici i koloni, još uvijek osjećali. ${ }^{16}$

Dok je vrijeme na prijelomu stoljeća vrijeme zastoja nacionalnog pokreta, istodobno su se odvijale važne aktivnosti narodnjaka na pravno-političkom, gospodar-

i Slovenaca u prvom je redu bio program gospodarskoga i socijalnoga oporavka seljaštva, stvarne snage nacionalnoga pokreta. U političkom smjeru djelovanja borba Narodne stranke za ravnopravnost naroda očitovala se u borbi za proširenje izbornog prava građana, čime bi se omogućilo osvajanje općinskih vlasti i postizanje veće zastupljenosti Hrvata i Slovenaca u Istarskom saboru i Carevinskom vijeću. Narodna stranka zalagat će se za ravnopravnost jezika u autonomnim tijelima Pokrajine te za razvoj hrvatskih i slovenskih prosvjetnih i kulturnih institucija. Vjekoslav Bratulić, „Političke stranke u Istri za vrijeme narodnog preporoda”, Hrvatski narodni preporod u Dalmaciji $i$ Istri, Zagreb, 1969., 299; isti, „Zapisnici sjednica 'Hrvatsko-slovenskog kluba' zastupnika u Istarskom saboru 1901-1909”, Vjesnik historijskih arhiva u Rijeci i Pazinu, XIV, 1969., 299-384; isti, „Zapisnici sjednica 'Hrvatsko-slovenskog kluba' zastupnika u Istarskom saboru (1884-1901)', 123-199; Petar Strčić, "O pravaštvu u Istri i na Kvarnerskim otocima krajem 60-tih i početkom 70-tih godina 19. stoljeća", Historijski zbornik, XXIX-XXX, 1976.-1977., 347-364; Darko Dukovski, Svi svjetovi istarski, Pula, 1997., 151-152; isti, „Hrvatsko-slovenska narodna stranka”, Istarska enciklopedija, 311; S. Žitko, 36-39, 44-45; J. Kramar, 116-133.

Željko Klaić, „Nacionalni pokret istarskih Hrvata i Slovenaca na prijelomu XIX. u XX. stoljeće i utemeljenje Političkoga društva za Hrvate i Slovence u Istri 1902.”, (dalje: „Nacionalni pokret istarskih Hrvata i Slovenaca na prijelomu XIX. u XX."), Histria, 4, 2014., 53.

Vjekoslav Zidarić, „Razvitak zadrugarstva u Istri i njegova uloga u narodnom preporodu“, Hrvatski narodni preporod u Dalmaciji i Istri, Zagreb 1969., 457-475; Josip Percan, „Materijalni i kulturološki značaj Laginjinih istarskih posujilnica“, Prilozi zavičaju, 4, 1986., 161-174; Željko Klaić, „Prilog proučavanju hrvatskih kreditnih zadruga i ostalih zadružnih organizacija u nekadašnjem pazinskom kapetanatu (kraj XIX. i početak XX. st.)“, (dalje: „Prilog proučavanju hrvatskih kreditnih zadruga“), Hrvatska čitaonica u Pazinu, Pazin, 1999., 217-227, 243-252; Beuc, Istarske studije, 244-249, 252-253. 
skom i kulturnom području, a to će voditi prevladavanju poteškoća. Utemeljenje i djelovanje političke organizacije istarskih narodnjaka, utemeljenje i djelovanje zadružnih organizacija i rad kulturnih institucija, uz neizostavnu demokratizaciju izbornog zakonodavstva za bečki parlament, kad je na temelju općeg izbornog prava glasa Hrvatsko-slovenska narodna stranka u Istri na državnim izborima 1907. ostvarila uspjeh, pokazatelji su prevladavanja poteškoća u razvoju pokreta.

Istarski narodnjaci podupirali su novu izbornu reformu za bečki parlament, zalagali su se za opće izborno pravo te su od novog izbornog reda očekivali jačanje svojih pozicija u Carevinskom vijeću. Međutim, njihove će težnje istodobno ići i prema Istarskom saboru, prema reformi zemaljskog izbornog reda, koji bi im omogućio veći utjecaj u autonomnim upravnim tijelima pokrajine. Političko društvo za Hrvate i Slovence u Istri održalo je širom Istre 1906. i 1907. čitav niz javnih sastanaka i skupština na kojima se podržavala nova izborna reforma za bečki parlament.

Dana 26. siječnja 1907. Car je sankcionirao izborni zakon na temelju kojega je u Austriji uvedeno opće i jednako izborno pravo za državne izbore. Izborima za bečki parlament, koji su održani 14. svibnja 1907., mogli su pristupiti svi muški austrijski državljani s navršene 24 godine i koji su na dan raspisivanja izbora najmanje jednu godinu obitavali u dotičnoj općini u kojoj su i obnašali svoje glasačko pravo. ${ }^{17}$

Hrvatsko-slovenski predstavnici Matko Mandić, Matko Laginja i Vjekoslav Spinčić na izborima 14. svibnja izabrani su gotovo jednoglasno u predviđenom četvrtom, petom i šestom izbornom kotaru, dok talijanski liberalni predstavnici nisu osvojili dovoljan broj glasova u predviđenom prvom, drugom i trećem izbornom kotaru. Matko Laginja ušao je osim toga u uže izbore u drugom, porečkom, i trećem, pulskom izbornom kotaru. Treba reći da su za narodnjaka Laginju dolazili glasovi i iz redova talijanskih seljaka iz pulske okolice. Bila je to posljedica njegova gospodarskog rada, ne samo za hrvatsko i slovensko seljaštvo, već i za talijanskog seljaka. Kod užih izbora 23. svibnja, u trećem, pulskom izbornom kotaru kandidat talijanskih liberala bio je Lodovico Rizzi, a u drugom, porečkom izbornom kotaru kandidat liberala bio je Matteo Bartoli. Felice Bennati kao kandidat talijanskih liberala trebao je biti kod užih izbora suprotstavljen predstavniku talijanskih kršćanskih socijala Pietru Spadaru u prvom, koparskom izbornom kotaru. ${ }^{18}$

$\overline{17}$ Vasilij Melik, „Demokratizacija volilnega sistema (1907) in njeni učinki“ Zgodovinski časopis, 33, 2, 1979., 221; Boris Gombač, „,Slovenska politika v Trstu v desetletju pred prvo svetovno vojno.“ Zgodovinski časopis, 33, 2, 1979., 255; B. Benussi, Povijest Pule u svjetlu municipalnih ustanova do 1918. godine, 608; J. Kramar, 58.

18 Na državnim izborima 14. svibnja 1907. talijanski glasovi bili su razdijeljeni između nekoliko stranaka. Talijanski nacionalni liberali kao vodeća snaga kod Talijana imali su konkurente u talijanskim kršćanskim socijalima i talijanskim socijaldemokratima. U prvom izbornom kotaru „izvan stranaka”, tj. samostalno, kandidirao se „na agrarnom programu” Pier Antonio Gambini, ranije pripadnik talijanskih liberala. Na predizbornim sastancima, kako je pisao Matko Mandić, izražavale su se stranačke suprotnosti. Talijanski su liberali napadali talijanske kršćanske socijale i talijanske socijaldemokrate, ali glavni su im protivnici ipak bili istarski narodnjaci. Kršćanski socijali i soci- 
Uspješni izborni rezultati hrvatsko-slovenskih kandidata na državnim izborima 1907. vodili su promjeni odnosa snaga između istarskih Slavena i Talijana.

\section{Općinski izbori u Tinjanu}

Nisu samo rezultati državnih i zemaljskih izbora na prijelomu XIX. i XX. stoljeća utjecali na utemeljenje političke organizacije istarskih narodnjaka već je i značenje općina i općinskih izbora ukazivalo na potrebu izgrađivanja čvrste organizacije na terenu, u prvom redu u seoskim sredinama, otkud je dolazila odlučujuća potpora nacionalnom vodstvu. Čitav je niz pripadnika seljaštva, ali i drugih pojedinaca, djelovao u gospodarskom, kulturnom i političkom smjeru, a na to se djelovanje i oslanjaju narodni prvaci. Dobar primjer i pokazatelj prilika u općinama na početku XX. stoljeća bili su općinski izbori u Tinjanu održani 1902. i 1903. Izbori su pokazatelj previranja unutar hrvatskih izbornih redova.

Istarski su narodnjaci u vremenu kraja XIX. stoljeća učvrstili svoje pozicije $u$ mjesnoj općini Tinjan, a početkom XX. stoljeća gube općinsku upravu. Početkom XX. stoljeća, nakon uspješnih izbora održanih na kraju XIX. stoljeća, pojavit će se u Tinjanu pitanje odnosa unutar hrvatskog izbornog tijela. Umjesto dotadašnjeg jedinstva javljaju se sukobi. Posebno su u Tinjanu bili apostrofirani načelnik Šime Defar i Venceslav/Vjenceslav Križmanić iz Ježenja.

U izbore u tinjanskoj općini uključili su se pristalice istrijanskog pokreta Ivana Krstića, kao i on sâm, a i Talijanska liberalna stranka, koja ga je podržavala. Krstić je bio iz Arbanasa kod Zadra, nastanio se u Matuljima i već od 1895. i 1896. djeluje na kastavsko-liburnijskom prostoru protiv hrvatstva i istarskih hrvatskih nacionalnih prvaka. Prije se isticao kao veliki Hrvat, da bi inspiriran talijanskim liberalima s pokrenutom Pravom našom slogom počeo pisati i djelovati protiv Narodne stranke i njezinih prvaka. U svojem djelovanju nije se ograničavao samo na spomenuti prostor već i na druge dijelove pokrajine, a primjer su upravo općinski izbori u Tinjanu na početku XX. stoljeća. Njegov list protivnici su podrugljivo nazivali „mačji list”, a njega „mačjak”, jer je stanovao kod "tete Ambrozije”, koja, govorilo se, ima trideset mačaka. ${ }^{19}$

jaldemokrati nisu ostajali dužni liberalima, ali su napadali i Hrvatsko-slovensku narodnu stranku. Prvi su prikazivali Narodnu stranku kao „liberalce” i kao „prenapete narodnjake”, a drugi su je prikazivali kao „klerikalce” i „,natražnjake”. Uspješni izborni rezultati hrvatsko-slovenskih narodnjaka 14. svibnja promijenit će odnose između talijanskih stranaka, što je došlo do izražaja na užim izborima 23. svibnja. Međusobno suprotstavljene talijanske stranke, liberali, kršćanski socijali i socijaldemokrati nakon 14. svibnja drugačije će nastupiti. Među istarskim narodnjacima nastupanje talijanskih kršćanskih socijala i talijanskih socijaldemokrata na užim izborima 23. svibnja smatralo se nedosljednim, nedostojnim, nelogičnim, ali za narodnjake ipak razumljivim jer "da su oni jedni i drugi najprije Talijani, onda tekar socijal-demokrati i kršćanski socijalisti”. M., „Izborne pobjede u Istri i u Trstu", Veliki Ćiril-Metodski koledar za prestupnu godinu 1908., Zagreb, 1907., 26-30; D. Šepić, „Nacionalna borba u Istri i izbori za Carevinsko vijeće 1907.", 418-420, 422. D. Šepić navodi da je autor članka u Ćiril-Metodskom koledaru Matko Mandić. 
Narodna stranka u Tinjanu pobjeđivala je na izborima i prije 1887. te $\mathrm{u}$ kontinuitetu odnosi izborne pobjede od te godine. Pobijedila je u sva tri izborna tijela, ali - zbog talijanskog utoka - konstituiranje novog zastupstva održano je tek 8. kolovoza 1888. Za načelnika će biti izabran Šime Defar. Hrvatski jezik postaje službeni, odnosno uredovni jezik za sve vanjske i unutarnje poslove. Francesco Costantini i Adamo Mrach gube punomoć za obavljanje pravnih općinskih poslova, te se općinskim prokuratorom imenuje Ante Dukić. Narodna stranka pobijedila je i na izborima 1891. u sva tri izborna tijela te 1895. i 1899. Za načelnika je svaki put bio izabran vođa hrvatskih narodnjaka u tinjanskoj općini Šime Defar. Bio je trgovac i posjednik, povezan s ostalim hrvatskim narodnjacima središnje Istre, ali i šire. Već je 1888., na godišnjoj skupštini Političkog društva Edinost iz Trsta, bio izabran za jednog od njegovih povjerenika iz Istre. ${ }^{20}$ Godine 1903. u tinjanskoj općini dolazi do preokreta - Defarova stranka gubi izbore - a za načelnika je izabran Venceslav Križmanić. Izabran je za načelnika i 1907. Općenito, hrvatski autori Defarov poraz i poraz njegove stranke obrazlažu talijanskom propagandom, zaduženošću seljaka kod talijanskih trgovaca i posjednika, nedovoljno izgrađenom nacionalnom svijesti te sukobima $u$ hrvatskim redovima. Križmanić nije bio Talijan, ali je bio pod njihovim utjecajem, ${ }^{21}$ pod utjecajem talijanskih liberala.

$\overline{19}$ Krajem XIX. i početkom XX. stoljeća na slabljenje pozicija istarskih narodnjaka utjecat će istrijanski pokret Ivana Krstića, koji je bio povezan s Talijanskom liberalnom strankom i koja ga je novčano potpomagala. Krstićev je pokret uspio pridobiti dio narodnjaka s kastavsko-liburnijskog prostora. Tako su za protivnike istarskih narodnjaka na državnim izborima 1897. i 1901. dolazili glasovi i iz nekih hrvatskih i slovenskih sredina. Svojom aktivnošću Krstić je namjeravao pridobiti pristalice i u drugim predjelima istarske pokrajine. Sa strane talijanske propagande i Krstićeva istrijanskoga pokreta nastupalo se smišljeno, predbacivalo se vodstvu Narodne stranke da misli samo na priključenje Istre Hrvatskoj, a ne i na stvarne potrebe istarskoga stanovništva, da je u Hrvatskoj loše gospodarsko stanje, da seljaštvo plaća visoke poreze i da živi u bijedi. Krstić se, među ostalima, povezivao i sa socijalistima. Vodstvo Narodne stranke trebalo je uložiti mnogo energije i rada da bi se suzbila opasnost. Sâm Krstić više je puta sudski kažnjavan. Umro je u riječkoj umobolnici 1906. „Kako gospodare istarski Talijani z našemi beči. Interpelacija zastupnika Spinčića i drugova na Njegovu Preuzvišenost gospodina ministra predsjednika kao upravitelja ministarstva nutarnjih poslova i na Njegovu Preuzvišenost gospodina ministra financija.", Narodni list, Volosko-Opatija, 27. studenog 1902.; Vjekoslav Spinčić, Narodni preporod u Istri, u: Dane Gruber, Povijest Istre - Vjekoslav Spinčić, Narodni preporod u Istri, Zagreb, 1924., 280-281; „Istra pred 50 godina“, Istarska Danica 1951., Pazin, 1950., 72-74; Dragovan Šepić, „O procesu integracije hrvatske nacije u Istri“, Društveni razvoj u Hrvatskoj od 16. do početka 20. stoljeća, Zagreb, 1981., 264-265; isti, Šepić, „Nacionalna borba u Istri i izbori za Carevinsko vijeće 1907.“, 403, 405; Goran Crnković, „Pokušaji i učinci protuhrvatske promidžbe Ivana Krstića u Klani“, Zbornik Društva za povjesnicu Klana, 4, 1998., 63-70; Stipan Trogrlić, „'Istrijanski pokret' Ivana Krstića“, Istarska Danica 2003., Pazin, 2002., 156-159; V. Bratulić, „Političke stranke u Istri za vrijeme narodnog preporoda“, 313-319, 332; B. Milanović, Hrvatski narodni preporod u Istri, II, 63-65, 73-75, 255-259, 420-421, 430; N. Šetić, 102; J. Kramar, 55.

21 Božo Milanović, „,Nekadašnje istarske općine“, Istarska Danica 1977., Pazin, 1976., 97; isti, Hrvatski narodni preporod u Istri, II, 179-182, 623; Ivan Grah, „Tinjan“, Istarska Danica 1982., Pazin, 1981., 98-100. 
Kronološki, zbivanja u vezi s tinjanskim izborima izgledala su ovako. Na izborima u rujnu 1902. pobjeđuje Hrvatska stranka. Protustranka, protivnici Šime Defara, upućuje utok, a Namjesništvo u Trstu poništava izbore. Novi su izbori održani u siječnju 1903. U trećem tijelu pobjeđuje Hrvatska stranka i te rezultate Namjesništvo u Trstu priznaje. U drugom tijelu pobjeđuju protivnici Šime Defara, Namjesništvo priznaje te rezultate, ali poništava izbore za prvo tijelo koje je osvojila Hrvatska stranka. Naknadni izbori za prvo tijelo održani su 30. ožujka 1903. i na njima pobjeđuju protivnici dotadašnjeg načelnika. Tako su na osnovi pobjede u dva izborna tijela protivnici Šime Defara mogli imenovati svojeg načelnika.

Tinjanska mjesna općina bila je etnički gotovo potpuno hrvatska općina. Pod nju su spadale porezne općine Tinjan, Kringa i Sv. Petar u Šumi. ${ }^{22}$

Hrvatski narodnjaci na prijelomu stoljeća pokreću važne aktivnosti. Godine 1898. ustanovljeno je Tinjansko društvo za štednju i zajmove. Ono je ustanovljeno na skupštini u Tinjanu 7. studenoga 1898. sudjelovanjem Istarske posujilnice u Puli. U zadružni registar društvo je upisano odlukom C. kr. okružnog suda u Rovinju 7. siječnja 1899., a svoje pravo djelovanje zadruga je počela u ožujku 1899. Od potpore koju je C. kr. ministarstvo poljodjelstva dalo Istarskoj posujilnici u Puli za osnivanje takvih društava tinjanska je posujilnica dobila novu željeznu blagajnu, sve potrebne tiskanice i knjige te „prvu pomoć novčanu i zagovor kod 'Ljudske posujilnice' u Ljubljani". Među imenovanima u prvi upravni odbor Tinjanske posujilnice nalazila su se braća Ivan i Šime Defar. Ovaj drugi bit će dugogodišnji upravitelj Tinjanskog društva za štednju i zajmove. Po svojem kapacitetu Tinjanska zadruga bila je jedna od snažnijih zadruga Raiffeisenova tipa zadruga s neograničenim jamstvom. Iste godine u Tinjanu se pokreće i djelovanje Hrvatske čitaonice. Sjedište Čitaonice bilo je od 1898. u kući Điđe Mogorovića, a od 1900. u kući Ivana Defara. U Pokretačkom odboru za osnivanje Čitaonice bili su svećenik Eduard Gržetić kao predsjednik, Šime Defar kao potpredsjednik, tajnik Venceslav Križmanić i odbornici Šime Ivetić i Ivan Defar. Nakon što je Namjesništvo u Trstu odobrilo pravila uslijedilo je 16. rujna 1900. otvaranje Hrvatske čitaonice u Tinjanu. Na osnivačkoj skupštini u prvi odbor Čitaonice izabrani su Eduard Gržetić kao predsjednik, Šime Defar kao potpredsjednik, učitelj Fran Baf kao tajnik i odbornici Josip Križmanić i Šime Ivetić. Čitaonica veoma brzo počinje primati više raznih izdanja hrvatskih i slovenskih političkih, gospodarskih i vjerskih novina i časopisa, između ostalih Obzor, Našu slogu, Katoličku Dalmaciju, Dom i svijet, Pučki list, Edinost, Gospinu krunicu i dr. U idućim godinama broj raznih časopisa i novina samo se povećavao. ${ }^{23}$ Upravo će pisanje Obzora pokre-

22 Cadastre national de l'Istrie (d'après le Recensement du $1^{\text {er }}$ Octobre 1945), Sušak, 1946., 211-215; Prezimena i naselja u Istri II., Prema Cadastre national de l'Istrie i drugim izvorima, priredili Josip Bratulić i Petar Šimunović, Pula - Rijeka, 1985., 64-73. 
nuti diskusiju i polemiku u povodu poraznih po Narodnu stranku općinskih izbora u Tinjanu 1903.

Dopisi upućeni vološćansko-opatijskom Narodnom listu govore o raspoloženju i prilikama u vrijeme pred izbore u Tinjanu 24. i 25. rujna 1902. te o aktivnosti pristalica Ivana Krstića. Tako jedan dopisnik govori o njihovu djelovanju, kako su „mački” i „,mačkići” podigli rep, kao da su već „podeštati” i „,kunžiljeri”, tj. načelnici i članovi općinskog zastupstva: „Obermačak u Kringi blezga da Defar neće bit već podeštat i da on je već sve obrnul koje je mogel, samo one pametne da ne more.” Da je „pomačil onog mladog golubaticu iz Ježenja. Njega sam ja ušempijal da će bit podištat, a sad je gorji od mene. Piše već svako rugo proti podištatu i plovanu u Pravoj Slogi, se druži samo s nami i s Talijani u Tinjanu, a bome znaš da sam meštar, kad sam ga omrazil od plovana, podeštata i učitelja. - Lani je predstavljal u čitalnici i pisal proti mačkom a sada piše sve proti Hrvatom." „Obermačak” - osvrće se dalje dopisnik u vezi djelovanja ovog, navodeći pri tom i njegovoe riječi - kako je nagovarao „onog mladog golubaticu iz Ježenja” pisati protiv Defara, koji „,da je pojel komunu da je prevaril, da je slepar i ča je znam ča god mi je vrag na pamet donesal, ali za sve to podištat ne mari”. Dopisnik na kraju članka spominje „kancelariju i agenciju Krstićeve Slo$\mathrm{ge}^{\prime \prime} \mathrm{u}$ Tinjanu. ${ }^{24}$ Sigurno da se ovo posljednje odnosi na dopisništvo Krstićeve Prave naše sloge. Kad spominje „onog mladog golubaticu iz Ježenja”, riječ je o Venceslavu Križmaniću.

Isto tako u jednom dopisu Narodnom listu očito se radi o reakciji na djelovanje pristalica I. Krstića u Tinjanu, govori se o zaslugama općinske uprave sa Š. Defarom na čelu; da je napravljena lijepa općinska zgrada, da je popravljen crkveni toranj u Tinjanu i Sv. Petru u Šumi, uređena „šterna”, odnosno zdenac u Kringi, prošireno groblje u Tinjanu i u Sv. Petru u Šumi, podignuta Kalvarija, koja je ures u Tinjanu, te da je podignut visoki kameni križ na Velom vrhu. ${ }^{25}$ Povrh toga načelnik ima mnogo posla i s posujilnicom - tj. s Tinjanskim društvom za štednju i zajmove - što znaju samo oni koji se prihvate takvog posla, i to obavlja bez ikakve plaće. ${ }^{26}$

graničeno jamčenje. Tinjan, 31/10 1903. Slavnomu C. Kr. Kotarskomu Poglavarstvu u Pazinu.", Udruženja 1903., kutija 88; „,Tinjansko društvo za štednju i zajmove, registrana zadruga na neograničeno jamčenje. Tinjan, dne 28 Augusta 1906. Slavnomu C. Kr. Kot. Poglavarstvu u Pazinu.", Udruženja 1906., kutija 101; „,Tinjansko društvo za štednju i zajmove, registrana zadruga za neograničeno jamčenje. Tinjan, dne 2 Augusta 1909. Slavnomu C. Kr. Kot. Poglavarstvu u Pazinu.", Udruženja 1909., kutija 111. (dalje: DAP, KPP, Udruženja, kutija); Branimir Crljenko, „,Stožerno mjesto hrvatskog duha. Uz stotu obljetnicu Hrvatske čitaonice Tinjan.", Dometi, Br. VII-XII, Rijeka, 1999., 87-94; Enrico Depiera, Hrvoje Defar, Tinjan i njegova prošlost, Tinjan 1997., 76, 81; Ž. Klaić, „Prilog proučavanju hrvatskih kreditnih zadruga", 228-229, 232-233, 235; V. Zidarić, 464. 
Pisanje Narodnog lista $^{27}$ 1902. ide ponajprije u smjeru obrane hrvatskih interesa od pokreta Ivana Krstića, pokreta koji, kako piše list, potkupljivanjem, obmanjivanjem zaduženih hrvatskih seljaka, uz potporu Talijanske liberalne stranke, pridobiva njihove izborne glasove. Pisanje glasila ne ukazuje na odnose unutar hrvatskih izbornih redova u Tinjanu već samo konstatira kako se krstićevci hvale zato što su, kaže, pridobili pristalice, a pridobili su i „onog mladog golubaticu" Venceslava Križmanića. ${ }^{28} \mathrm{U}$ tom je smislu jedno pisanje Naše sloge - na koje je upozorio Božo Milanović ${ }^{29}$ - sadržajno nešto drugačije u odnosu na pisanje Narodnog lista. Dopisnik u Našoj slozi u povodu predstojećih izbora navodi: „U obližnjem Tinjanu obaviti će se naskoro obćinski izbori. Po kretanju mačića sudeć, boriti će se dvie stranke. Pa da bi zašto! Koliko nam je znano, po sredi su jedino osobnosti, kojih bi moralo nestati sa površja, kad se radi o dobrobiti narodne stvari, radi toga se nadamo, da će dosadanji velevriedni načelnik tinjanski sa palmom mira u ruci učiniti potrebne koraake, da se disidenti hrvatske stranke privedu opet u naše narodno kolo, gdje bi lahko sviukupno radili na korist rodne si obćine." ${ }^{30}$ Pisanje je zanimljivo i upućuje na di-

$\overline{27}$ Narodni list pokrenuli su krajem studenog 1900. Viktor Car Emin i Ivan Pošćić kako bi se suzbila aktivnost Talijanske liberalne građanske stranke da pomoću djelovanja Ivana Krstića pridobiva hrvatske i slovenske glasače osobito na kastavsko-liburnijskom prostoru, i to baš u vrijeme kad su se trebali održati izbori za bečki parlament. Narodni list prestaje se tiskati 18. prosinca 1902., da bi ponovno počeo izlaziti 7. siječnja 1904. Prestaje izlaziti 20. listopada 1904.: „Našim prijateljem do znanja”, Narodni list, Volosko-Opatija, 18. prosinca 1902.; „Naše obećanje”, Narodni list, Volosko-Opatija, 7. siječnja 1904.; „Domaće viesti. 'Narodi list' prestaje.", Narodni list, Volosko-Opatija, 20. listopada 1904.

Tek nakon prekida izlaženja Narodnog lista krajem 1902. i njegova ponovnog izlaska početkom 1904. pojavit će se u glasilu primjedba da u radu nekih općina koje su u hrvatskim rukama nešto nije $u$ redu. Takvo je reagiranje ipak u prvom redu proizlazilo iz poraznih rezultata tinjanskih izbora 1903. i iznesenih suprotstavljenih pogleda u povodu toga, kao i burnih općinskih izbora koji su uslijedili nakon tinjanskih te problema koji su se javljali prilikom utvrđivanja i djelovanja Političkog društva za Hrvate i Slovence u Istri nakon njegova utemeljenja u svibnju 1902. Vjekoslav Spinčić kao predsjednik Političkog društva i njegov tajnik Gjuro Červar na razna su se pitanja oko rada organizacije te o samim provedenim općinskim izborima, osvrtali na godišnjoj skupštini Političkog društva u Pazinu 7. travnja 1904. Narodni list koji je ponovno počeo izlaziti 7. siječnja 1904. prije nije posebno pisao o odnosima unutar redova hrvatskih općinara niti je pisao o gubitku hrvatskog utjecaja, kako će to pisati dopisnici Obzora u siječnju i početkom travnja 1903. Sada je objavljen u Narodnom listu članak „Naše obćinske uprave”, u kojem, između ostalog, stoji: „Nećemo spominjati nikakvih imena jer su imena zazorna; spomenuti ćemo samo to, da se je u zadnje vreme konstatiralo, da u par naših obćina u Istri nije sve u redu. Žalostno je, kad mi sami moramo iznašati to u javnost, ali: 'težkoj boli gorki liek'. Tužbe naroda postaju sve glasnije, da se u par naših obćina ne upravlja onako kako bi se u interesu naroda moralo, da obćinski činovnici ne vrše svoju dužnost onako kako bi morali, da sa narodom postupaju grubo kako da je narod tu za njih a ne oni za narod." „Naše obćinske uprave”, Narodni list, Volosko-Opatija, 28. travnja 1904.

30 „Pazinski kotar: Iz Pazinšćine primamo.“, Naša sloga, Pula, 1. kolovoza 1902. Međutim, narodno glasilo već je 1899. navelo jedan slučaj koji bi mogao upućivati i ukazivati na izražavanje nekog nezadovoljstva prema tinjanskom načelniku, premda je riječ o isprici Giovannija Volticha iz Tinjana. Spomenuti se očitovao pred svjedocima da sve klevete, ogovaranja i laži koje je izgovorio 28 . veljače vozeći se u vlaku od Rovinja do Kanfanara, „vrhu poštenja i dobrog glasa velečastnog g. Antona Kjudera župnika, i g. načelnika Šimuna Defara u Tinjanu, su sasvim neistinite i od mene izmišlje- 
ferencijaciju unutar hrvatskog izbornog tijela na početku XX. stoljeća, s obzirom na tinjansku općinu. Ali nakon poraznih izbora 1903. stavovi izraženi u glasilima radikalizirat će se, pa će tako dopisnici Obzora kritizirati Političko društvo za Hrvate i Slovence u Istri zbog izbornih rezultata, a neki dopisnici Naše sloge navesti da unutar narodnog vodstva u Tinjanu postoji težnja za monopolizacijom u vlastitoj aktivnosti, s tim da će istodobno odbacivati optužbe upućene vodstvu Političkog društva za nedjelotvornost i odbacivati kritike da se radi o nazadovanju nacionalnog pokreta.

Na još jedan bitan moment $u$ povodu izbora u Tinjanu u rujnu 1902. ukazuje Naša sloga. To je pitanje zaduženosti seljaštva kod talijanskih posjednika. Glasilo je naime došlo u posjed pisma koje upućuje 1. rujna 1902. motovunski posjednik Antonio Corazza izbornicima u tinjanskoj općini. Pismo je objavljeno u hrvatskom prijevodu i u njemu motovunski posjednik zagovara izbor Venceslava Križmanića. Glasilo navodi kako se „talijanškim agitatorom” priključio i motovunski posjednik koji u tinjansku općinu upućuje dva tipa pisma, u jednom „pozivlje one, koji su mu dužni, da mu dug plate ili da glasuju za izdajničku stranku, a drugimi koji su mu jednom dužni bili, piše zatvorena pisma, kojimi ih pozivlje, da glasuju za talijanašku stranku". U pismu koje je došlo u ruke pazinskog dopisnika, između ostalog, stoji:

„Gospodine!

Obzirom na težko i nesnosno stanje, u kojem se nalazi vaša obćina, potrebito je, da izadje iz budućih izbora takvo zastupstvo, koje će si u istinu na srce uzeti sudbinu i velike potrebe onog pučanstva.

Neplašite se grožnja bilo s koje strane, već dajte vaš glas puštajuć se voditi jedino od vaše saviesti. Svi se sakupite okolo gosp. Venceslava Crismanicha, ${ }^{31}$ njega pitajte za savjet, u njega pouzdajte se. Njegovo poštenje, njegova spospbnost te velika ljubav, koju izkazuje - kako vam je poznato - obćini, jesu vam jamstvom, da će se on brinuti za vaše koristi, i samo za vaše koritsti, nikada za svoje.

Uplivajte na vaše rodjake i prijatelje, da uzmogne čvrsti brojem i slogom sa stalnošću postignuti ono, što mora ležati na srcu svakog dobrog Tinjanca." ${ }^{\prime 2}$

Nije nevažan podatak da je u Tinjanu započela djelovati i talijanska zadruga Cassa rurale di Antignana - a to je moralo voditi jačanju suprotnosti gospodarskog djelovanja u općini, jer otprije postoji Tinjansko društvo za štednju i zajmove. Talijanska zadruga u prvoj godini poslovanja, 1902., imala je 109 članova. ${ }^{33}$

ne“. Opoziva sve što je izrekao protiv njihova poštenja i moli sve one Kanfanarce i druge suputnike, koji su se s njim onom prigodom vozili u kupeu, „da ništa od onoga nevjeruju“, jer mu je danas žao da je naše glavare teško uvrijedio. Zahvaljuje ,,javnim putem“ župniku Antonu Kjuderu i načelniku Šimi Defaru, koji su mu, iako „uvriedjeni, iz prave kršćanske ljubavi“ uvredu „milostivo oprostili. U Tinjanu, dne 3. marča. 1899.“ Potpisani su Giovanni Voltich, Ivan Defar, svjedok, Carlo Bottegaro, svjedok, Anton Pajca, svjedok. „Očitovanje“, Naša sloga, Trst, 9. ožujka 1899.

Ime i prezime u Našoj slozi posebno su istaknuti.

32 „Pazinski kotar: Krnjelsko-talijanaške spletke u Tinjanu.“, Naša sloga, Pula, 18. rujna 1902.

33 „Cronaca. Cassa rurale di Antignana.", L'Istria, Parenzo, 14. febbraio 1903. 
Na općinskim izborima u Tinjanu održanima 24. i 25. rujna 1902., po izvještavanju Narodnog lista, Hrvatska narodna stranka iznijela je pobjedu u svim trima izbornim tijelima bez obzira na talijanski pritisak kojim se htjelo pridobiti glasove zaduženih hrvatskih seljaka. Kod održavanja izbora boravili su u Tinjanu predstavnici Talijanske stranke iz Pazina, ali i sâm Ivan Krstić. On se, zbog sudskog postupka koji se vodio protiv njega, nije smio pojavljivati u javnosti već je boravio u kući svojih istomišljenika. Istodobno glasilo spominje i to da se na talijanskoj strani počelo pričati kako su kod tinjanskih izbora Hrvati pobijedili zbog nezakonitosti. ${ }^{34} \mathrm{Na}$ sjednici vodstva Istarskoga političkog društva (Società Politica Istriana) 6. listopada 1902. u Trstu njegov predsjednik odvjetnik Felice Bennati, između ostalog, govorio je i o tome da su zbog izbora u Tinjanu uputili reklamaciju. ${ }^{35}$

Narodni list, kad prati tinjanske općinske izbore 1902., ne zadržava se samo na njima nego ih povezuje s ostalim nadolazećim općinskim izborima, ali i sa širom političkom situacijom. Skreće pozornost na moguću opasnost koja prijeti općinama u kojima su hrvatski narodnjaci stekli pozicije. Piše da Talijanska stranka preko Ivana Krstića pokušava osvojiti tinjansku općinu. Ali, piše i da se tu krije i mnogo veća namjera - preuzeti na novim izborima i općine Žminj i Boljun - i tako zaokružiti pazinsku općinu u željezni obruč kako bi se u budućnosti preuzelo i tu općinsku upravu. ${ }^{36}$

U pisanju glasila primjećuje se bojazan od mogućega gubitka utjecaja istarskih narodnjaka u središnjoj Istri. Premda će i nadolazeći općinski izbori biti dinamični i burni, ipak je Narodna stranka nakon tinjanskih izbora u središnjoj Istri sačuvala svoje pozicije, pa krajem 1903. osvojila i Općinu Roč, koju je do tada držala Talijanska liberalna stranka.

Poništeni izbori u Tinjanu od rujna $1902 .{ }^{37}$ na hrvatskim su narodnjacima morali ostaviti traga u smislu narušavanja dotadašnjeg jedinstva izbornih redova, premda

34 „Krstić i opet odsudjen“, Narodni list, Volosko-Opatija, 11. rujna 1902. „Domaće viesti. Izbori u Tinjanu.", Narodni list, Volosko-Opatija, 18. rujna 1902.; „Narode probudi se!“, Narodni list, Volosko-Opatija, 2. listopada 1902.; „Dopisi. Iz Tinjana.", Narodni list, Volosko-Opatija, 2. listopada 1902.

"Cronaca. Società politica istriana.“, L'Istria, Parenzo, 11. ottobre 1902.; Usput: „Notiziario cittadino Società politica istriana.", Il Giornaletto di Pola, Pola, 8. ottobre 1902.

U glasilu se navodi i to da su, uz političku prevlast, Talijani istodobno namjeravali i hrvatsko seljaštvo podčiniti i uništiti ga tako da se više nikad ne podigne, a krajnji je cilj bio da se Istra pripremi za priključenje Italiji. U prilog takvom mišljenju idu i manifestacije oživjelog iredentizma u susjednoj Italiji. Narodni list postavlja pitanje kako se u takvoj situaciji ponaša Vlada u Beču, istodobno dajući odgovor: „Švabe va Beče reć bi, da su malo, ali samo malo progledali. Oni sami ne znaju ča bi storili. Oni bi radi ukrotit Talijane, ale opet njim ne bi milo bilo, da se mi tim okoristimo. Švabe z Beča bi oteli, da se Talijane ukroti ali u korist Njemaca, tako da bi oni radi pripravili Trst i Istru za njihove lancmane - Nemce." Premda se glasilo mnogo bavi suprotstavljanjima hrvatskih narodnjaka i talijanskih liberala - naglašava i širenje iredentizma u susjednoj Italiji - ono jasno precizira i njemački utjecaj, opasnost od pangermanstva. „Izbori va Tinjane“, Narodni list, Volosko-Opatija, 9. listopada 1902. 
su izborni rezultati išli njima u prilog, pa su mogli očekivali da će na novim izborima ipak odnijeti pobjedu. Ali su naznake diferencijacije unutar hrvatskog izbornog tijela njima bile uočljive. Stavovi će se radikalizirati nakon općinskih izbora u siječnju i krajem ožujka iduće, 1903. godine, kad Narodna stranka gubi izbore u Tinjanu, a to je dalo povoda dopisnicima Obzora koji su optuživali nacionalno vodstvo za nedjelotvornost i pasivnost u radu, što, dakako, nije imalo temelja. Dopisnicima $O b$ zora tinjanski su izbori bili povodom za pisanje o zastoju i nazadovanju u razvoju nacionalnog pokreta na prijelomu stoljeća.

Nakon poništenih izbora u Tinjanu u rujnu 1902., novi su zakazani za 12., 13., 14. i 15. siječnja $1903 .{ }^{38}$

\section{Obzor i općinski izbori u Tinjanu u siječnju i krajem ožujka 1903.}

Dopisnici Obzora, zbog rezultata općinskih izbora - pogotovo ovih u Tinjanu ali i drugih, prethodnih zemaljskih i državnih, bili su pesimistični prema nadolazećim općinskim izborima i kritični prema vodstvu nacionalnog pokreta. Dopisnici će ukazivati na zastoj u razvoju pokreta u Istri na prijelomu stoljeća, a tinjanski općinski izbori bili su im pokazatelj tog nazadovanja i pokazatelj slabljenja pokreta. Ipak, izrečeni sud dopisnika Istranina u Obzoru da hrvatstvo u Istri propada smatram neprihvatljivim. Između ostalog, dopisnici Obzora nisu spominjali gospodarski čimbenik - što ne znači da ga nisu uzimali u obzir - kad su govorili o nacionalnom pokretu. Dopisnik Istranin ne spominje Šimu Defara, ali se osvrće na tek održane siječanjske izbore. U trećem tijelu dobili su Hrvati 38 glasova većine, a u prvom tijelu 2 glasa većine. U drugom tijelu dobili su "talijanaši” 24 glasa većine. Ako se uzme u obzir da je izborna komisija bila sva u hrvatskim rukama i da su tinjanskom općinom oko 16 godina vladali Hrvati te da su pobjeđivali u sva tri izborna tijela, onda siječanjski izbori predstavljaju neuspjeh. Piše da su se među Hrvatima slavili rezultati izbora, ali da su isto tako slavili i „talijanaši”. ${ }^{39}$ Istranin nije zadovoljan pisanjem hrvatskih i slovenskih glasila u Istri i Trstu posljednjih 10 - 12 godina, kad je riječ o izbornim prilikama u Istri, jer, kako kaže, izborni su se rezultati u tom razdoblju uglavnom proglašavali hrvatskim pobjedama, međutim isti se rezultati u talijanskom tisku, dodaje, proglašavaju talijanskim pobjedama. Dopisnik je kritičan prema hrvatskom tisku jer ponajprije piše o hrvatskim pobjedama, o probuđenoj hrvatskoj svijesti u Istri i o onima koji su je probudili, ali upozorava da je stanje drugačije. Iako on po imenu spominje samo Našu slogu iz Pule i Edinost iz Trsta, u navedenom smislu promatra i pisanje ostalih novinskih glasila izvan Istre. Godina

38 „Pazinski kotar: Novi obćinski izbori u Tinjanu.“, Naša sloga, Pula, 8. siječnja 1903.; „Cronaca. Le elezioni in Antignana.", L'Istria, Parenzo, 10. gennaio 1903.

39 Porečka L'Istria piše da je u drugom tijelu pobijedila „lista italiana“. O provedenim izborima: „Cronaca. Le elezioni in Antignana.", L'Istria, Parenzo 17. gennaio 1903. 
1891., navodi dopisnik, bila je najsjajnija u političkom životu za istarske Hrvate, kad je Matko Laginja izabran u seoskim općinama zapadne Istre za Carevinsko vijeće u Beču. To se dogodilo usprkos talijanskoj agitaciji i pristranosti svih vladinih činovnika, od tršćanskog namjesnika do posljednjeg pisarčića. ${ }^{40}$ Otprilike $7-8$ godina nije bilo nikakvog znaka napretka, premda se još nije moglo govoriti o pravom nazadovanju. A onda se počelo „valjati niz brdo jedno za drugim”. Došli su izbori za Carevinsko vijeće 1900./1901. i Laginja je srušen relativno velikom većinom. ${ }^{41}$ Ubrzo su uslijedili i izbori za Istarski sabor krajem 1901., pri čemu su Hrvati ostali u istoj poziciji kao i u proteklih 12 godina. ${ }^{42} \mathrm{Ti}$ su izbori, piše, dobro pokazali na čemu su naši u Istri. Istranin se dalje osvrće na to kako su „naše novine” pisale da se nisu izgubile pozicije u općinama, da kod izbora hrvatski pouzdanici u seoskim općinama - odnosno kod izbora fiducijara u seoskim općinama - Hrvati nisu izgubili pozicije: „Što se tiče toga, da nisu ništa izgubili, dosta je spomenuti, da kad bi naši bili predobili sve one pozicije, koje i g. 1891., mjesto 8, imali bi svih 12 zastupnika seoskih općina. ${ }^{43}$ A kamo Poreč, Oprtalj i Višnjan, kamo Kanfanar i Sanvičenti? Jedna od najsjajnijih točaka hrvatske političke poviesti u Istri jesu izbori u Sanvičenti g. 1891. Sanvičenti je morao odlučiti, da li će zastupati zapadne seoske općine Talijan ili Hrvat, te se već zato može pomisliti, kako su agitirali Talijani, da si održe, ne osvoje, tu poziciju, pa ipak su propali, uzprkos svoj pripomoći vlade. ${ }^{44}$ Pa ipak se lani nisu

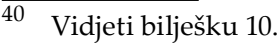

41 Misli se na rezultate glasovanja u petoj općoj kuriji: Felice Bennati dobiva 315 glasova, a Matko Laginja 285 glasa.

Od izbora 1889. do izborne reforme za Istarski sabor 1908., Hrvati i Slovenci imali su stalan broj od 9 zastupnika, 8 izabranih u kuriji seoskih općina i 1 u gradskoj kuriji u istočnoj Istri.

Izborima za Sabor održanima krajem 1901. Hrvati i Slovenci ostaju na istim pozicijama, osvajaju osam mandata u kuriji seoskih općina i jedan mandat u gradskoj kuriji u istočnoj Istri. Hrvati nisu uspjeli izabrati svoje zastupnike za Sabor u kuriji seoskih općina Kotarskog kapetanata Pula. Također nisu uspjeli ni u kuriji seoskih općina Kotarskog kapetanata Poreč. Prema tadašnjem izbornom zakonu, u kuriji seoskih općina izabiralo se za Sabor 12 predstavnika. Interesantno ovdje može biti razmišljanje Vjekoslava Spinčića kao protivnika nove izborne reforme za zemaljski sabor, kad je na sjednici Sabora 21. ožujka 1908. bio protiv ukupnog povećanja hrvatskih i slovenskih predstavnika na 19, a talijanskih na 25, jer, kaže Spinčić, poštivanjem zakona i većom angažiranošću u radu ipak bi prema starom izbornom zakonu istarski Hrvati i Slovenci mogli osvojiti svih 12 mandata kurije seoskih općina. Stenografski zapisnik hrvatskih govora na istarskom saboru u zasjedanju od 14. III. - 26. III. 1908., 12.-14., [s. a.]. Stab. Tip. Unione E. Meneghelli \& C. - Triste. U svom promišljanju Spinčić se približavao Obzorovu dopisniku, koji je također razmišljao da bi Narodna stranka po postojećem zemaljskom izbornom zakonu mogla osvojiti svih 12 mandata u kuriji seoskih općina.

Kod izbora za Carevinsko vijeće u ožujku 1891., pogotovo kod naknadnih izbora u listopadu, važnu ulogu odigrali su glasovi hrvatskih seljaka iz okolice Višnjana, Motovuna, Oprtlja, Kanfanara, Svetvičenta, koji na izborima osiguravaju pobjedu hrvatskih fiducijara. Sveukupno na izborima u listopadu fiducijari daju 108 glasova Matku Laginji, a njegov protukandidat Benedetto Polesini dobiva 104 glasa. Nacionalna borba u Istri na kraju XIX. stoljeća zaoštrava se, i kako je istaknuto, hrvatsko-slovenski nacionalni pokret gubi pozicije $\mathrm{u}$ nekim sredinama $\mathrm{u}$ Istri. $\mathrm{U}$ izborima za bečki parlament 1900./1901., kad se već bio razvio pokret Ivana Krstića, poraz M. Laginje u petoj generalnoj kuriji, gdje je pobijedio F. Bennati, Naša sloga objasnila je na sljedeći način. „Prema broju 
Hrvati tu niti prikazali, ${ }^{45}$ premda, kada bi bili dobili Sanvičenti i Kanfanar, u komu su propali za 1 cigli glas, bili bi dobili 2 zastupnika više u saboru." Rezultati izbora za Carevinsko vijeće, izbori za Sabor i općinski izbori - svakako oni u Tinjanu - bili su osnovica na kojoj dopisnik zaključuje: „Hrvatstvo propada u Istri.” Ističe da Naša sloga izlazi jedanput na tjedan, umjesto dvaput, kao prije. ${ }^{46}$ Postavlja pitanje što je s „hrvatskim političkim družtvom za Istru". Dopisnik nastavlja diskusiju navodeći da Hrvatima u Istri mora biti bolje jer imaju već dosta svojih škola. Istina da nepismen i neuk čovjek lako pada pod utjecaj raznih političkih agitatora, dok će se čovjeka koji je stekao neko osnovno znanje i kulturu na materinskom jeziku teško nahuškati protiv vlastitog naroda. Istina da u Istri ima dosta hrvatskih pučkih škola, koje su pod upravom pokrajine, a ova je u rukama Talijana, ali se takve škole nalaze samo $u$ onim mjestima u kojima bi se teško moglo suprotstaviti „talijanašima”. Ima mnogo sela gdje je potrebna hrvatska pučka škola, a tu nema nikakve, ili postoji talijanska. Postoji Družba sv. Ćirila i Metoda, ali ona nije u stanju zadovoljiti ni najpreče potrebe, pa ni, kad bi ga imala, Krezovo blago. Hrvati imaju i Pazinsku gimnaziju, premda nad njom visi Damoklov mač. No sve te škole potječu velikom većinom iz novijeg vremena i proteći će još mnogo vode do trenutka kad će se pokazati njihov uspjeh. Hoće li biti vremena da se to sve ispravi? Istranin nakraju navodi da se samo po sebi nameće pitanje: „Tko je kriv, da hrvatstvo nazaduje u Istri?"” Navodi: „Ja se ne mislim ovdje upuštati u razpravljanje toga pitanja; odgovor čeka istarske Hrvate."${ }^{\prime \prime 7}$

Obzorov je dopisnik u prvom redu nezadovoljan političkim rezultatima na prijelomu stoljeća, rezultatima državnih, zemaljskih, općinskih izbora, prozivajući tek nedavno utemeljenu novu političku organizaciju nacionalnog pokreta. Kritičan prema pitanju školstva, spominje talijansku upravu u pokrajini i na taj način spominje talijanski utjecaj, ali ne precizira utjecaj talijanskih liberala koji su desetljećima bili u prednosti, odnosno politički i gospodarski snažniji, pa su imali odlučujući utjecaj $\mathrm{u}$ autonomnim tijelima u pokrajini. Hrvatski i slovenski narodnjaci, gospodarski i

stanovnika peta kurija trebala je biti naša, ali je izgubljena zbog ovih razloga: 1) Izdani su certifakti fiducijarima u Škofijama, koji su izabrani na osnovi potpuno neurednih izbornih listina, izdani su certifakti fiducijarima izabranim u Svetvinčentu, gdje su se glasovi kupovali, i napokon, izdani su certifakti fiducijarima u Pomeru gdje je Talijanska stranka pobijedila s nekoliko glasova većine, jer su za nju glasovali neki koji nisu imali pravo glasa; 2) Na našu žalost, za talijanskog kandidata glasovali su fiducijari izbornih sekcija Rukavac, Veprinac, Lovran i Mošćenice. F. Barbalić.", Narodna borba u Istri od 1870. do 1915. godine, 91-92.

Misli se na zemaljske izbore krajem 1901.

Od 3. travnja 1900., broja 14, do 28. prosinca 1900., broja 89, Naša sloga izlazi utorkom i petkom. Tijekom 1901. izlaženje Naše sloge ostaje isto, da bi se vrijeme izlaženja promijenilo u idućoj 1902. Od 14. kolovoza 1902., broja 61, do 25. prosinca 1902., broja 80, list izlazi četvrtkom. Vrijeme izlaženja lista ostaje isto u 1903., u vrijeme kad dopisnik "Istranin" piše u Obzoru od 23. siječnja 1903., ali se početkom zasjedanja Istarskog sabora u Puli izlaženje lista ponovno promijenilo. Od 27. listopada 1903., broja 44, do 26. studenog 1903., broja 53, Naša sloga izlazi triput na tjedan. Tatjana Blažeković, „Bibliografski podaci o ‘Našoj slogi'”, Pazinski memorijal 1970., 2, MCMLXXI /1971./, 79. 
politički slabiji, djelovali su prema vlastima u Beču pozivajući se u svojim zahtjevima na temeljne državne zakone koji su propisivali ravnopravnost.

Uvijek se može postaviti pitanje djelotvornosti i uspješnosti u radu na političkom, gospodarskom i kulturnom planu onih koji su se u austrijskom pravnom sustavu oslanjali i pozivali na postojeću legitimnost, ali koji su u takvom dugogodišnjem i upornom radu ipak postizali rezultate. Istarski nacionalni prvaci, polazeći od iskustva dugogodišnjega desetljetnog suprotstavljanja talijanskim liberalima koji im $\mathrm{u}$ autonomnim zemaljskim tijelima nisu priznavali ravnopravnost, svoje zahtjeve upućuju vlastima pozivajući se na temeljne državne zakone. Bit će to kontinuitet u djelovanju istarskih narodnjaka, preko Političkog društva Edinost iz Trsta i Političkog društva za Hrvate i Slovence u Istri od 1902. Bio je to uporan i sustavan rad, ne samo u pravno-političkoj sferi nego i u gospodarskom i u kulturno-prosvjetnom smjeru, ali i u pogledu religijskih pitanja kao što je bio problem uporabe glagoljice i staroslavenskog jezika u bogoslužju. No, nije uvijek morao donositi rezultate. Govori, podneseni mnogobrojni zahtjevi i interpelacije u Istarskom saboru i Carevinskom vijeću te spomenice papi Piju X. bili su način uobičajenoga legitimnog rada hrvatskih i slovenskih predstavnika. Pozivajući se na legitimnost, istarski prvaci teško su mogli ostvarivati svoje zahtjeve jer je kurijalni sustav osiguravao prevlast imućnih, veleposjedničkih i građanskih slojeva, a tu su talijanski nacionalni liberali, kao predstavnici tih slojeva u Istri, bili u prednosti.

Nezadovoljan stanjem i položajem hrvatstva te kritičan prema izbornim rezultatima i položaju školstva, Obzorov Istranin proziva vodstvo i političku organizaciju nacionalnog pokreta. Međutim, treba dvojiti o tom pisanju i ocjeni Istranina kad se ona usporedi s drugim pogledima koji govore o položaju Hrvata i Slovenaca u Markgrofoviji Istri na početku XX. stoljeća. ${ }^{48}$

$\overline{48}$ Samo nekoliko godina nakon kritičkog pisanja Istranina u Obzoru, u povodu proslave 60. obljetnice održane u Kastvu 1908., Vjekoslav Spinčić na svečanom je banketu u svojem odgovoru i zahvali, između ostalog, istaknuo: „Preokret u Istri, gdje ima danas na stotine hrvatskih i slovenskih učitelja i učiteljica, gdje ima danas i hrvatski gimnazij i hrvatsko učiteljište; gdje se smije hrvatski govoriti i učiti; gdje ima do 30 općina, koje hrvatski ili slovenski pišu, gdje i c. kr. oblasti hrvatski jezik rabe. Preokret u ovoj općini (t. j. Kastavska općina, op. a.), gdje su još godina 1880-tih, pak i prije 12 godina štićenici i plaćenici c. kr. oblasti i zemaljskoga odbora digli hajku, djelomice s uspjehom, proti hrvatskomu imenu.“ U „Javnoj zahvali“ 31. listopada 1908., u povodu 60. obljetnice, za primljene čestitke Spinčić zahvaljuje svećenicima, doktorima, profesorima, učiteljima, učiteljicama, trgovcima, obrtnicima, seljacima i mnogim drugima širom Istre; općinama i općinskim upravama i njihovim načelnicima; čitaonicama, pjevačkim, sokolskim, gospodarskim i ostalim društvima; Istarskom klubu u Beču; Hrvatsko-slovenskom akademskom ferijalnom društvu „Istra“ u Pazinu i pogotovo svojim saborskim drugovima. Spinčić u stvari navodi socijalnu i profesionalnu širinu nacionalnog pokreta u Istri. Zahvaljuje dalje Političkom društvu za Hrvate i Slovence u Istri, koje je smatrao upravnim vijećem sveukupnog hrvatskog i slovenskog naroda u pokrajini. Zakljućuje: „Ja sam doživio velik preokret u hrvatskom i slovenskom narodu Istre u svih granah javnoga života." Spomen-knjiga proslave 60-godišnjice zastupnika naroda prof. Vjekoslava Spinčića u Kastvu 22. i 23. oktobra 1908. Uredili: Kazimir Jelušić i Vladimir Nazor. Kastav, 1909., 17-19, 97-98. 
Prema podacima Matka Rojnića i Nikole Žica, dopisnik Istranin jest Kastavac Milan Marjanović. ${ }^{49}$ Budući da je on predstavnik mlađeg naraštaja istarskih javnih radnika, predstavnik tadašnje Napredne omladine, aktivnog sudionika u Narodnom pokretu u Banskoj Hrvatskoj, njegovo se pisanje mora promatrati u kontekstu nastupanja mlađega nadolazećeg naraštaja koji će u Istri tražiti drugačiji, odnosno energičniji i brži nastup vodstva nacionalnog pokreta. Narodni pokret u Banskoj Hrvatskoj 1903. znatno je djelovao na podizanje nacionalne svijesti Hrvata i Slovenaca u Istri, ali je djelovao i na radikalizaciju stavova - u prvom redu kod pripadnika mlađeg naraštaja - kad je bilo u pitanju djelovanje i zauzimanje Političkog društva za ostvarenje ciljeva nacionalnog pokreta. ${ }^{50}$ Premda se neposredno ne primjećuje utjecaj zbivanja u Banskoj Hrvatskoj na dopisnikovo navođenje, on je očito postojao. ${ }^{51}$ Milan Marjanović bit će aktivni sudionik u otporu protiv vlasti bana Khuena 1903. u Banskoj Hrvatskoj. ${ }^{52}$

Smatram potrebnim navesti dosta općenitu ocjenu o listu Obzor, koji je kao glasilo imao utjecaj na mlađu generaciju. Obzor je redovito pisao o istarskim prilikama i

$\overline{49}$ Matko Rojnić, Nikola Žic, „Popis glavnih 'Obzorovih' članaka“, Obzor, spomen-knjiga 1860-1935, Zagreb, MCMXXXVI /1936./, 275.

Pod utjecajem prilika u Banskoj Hrvatskoj 1903. javljali su se prijedlozi za promjenom u uređivanju, odnosno pisanju Naše sloge. O tome: Željko Klaić, „Matko Mandić i pitanje Naša sloge u vrijeme utemeljanja Političkoga društva za Hrvate i Slovence u Istri“ (dalje: „Matko Mandić i pitanje Naše sloge“), Zbornik Kastavštine, XII, 2004., 74-75, 79.

51 Istranin, tj. Milan Marjanović piše svega nekoliko dana prije skupštine u Zagrebu 29. siječnja 1903. gdje je došlo do fuzije glavnih snaga hrvatske građanske oporbe protiv režima bana Khuena Héderváryja. Na skupštini su sudjelovali i parlamentarni predstavnici iz Istre i Dalmacije. Na skupštini je istupio i Dinko Trinajstić, potpredsjednik Političkog društva za Hrvate i Slovence u Istri. Založio se za ujedinjenje hrvatske oporbe. Izjavljuje „da su Hrvati u Istri navikli prelaziti preko stranačkih razlika na ozbiljan i složan rad u službi domovine“. On „pozdravlja u ime istarskih Hrvata ujedinjenje dviju hrvatskih stranaka /Misli se na Stranku prava, tzv. domovinaše, i na Nezavisnu narodnu stranku, tzv. obzoraše. Op. a./ i slogu nove hrvatske stranke prava sa čistom strankom prava“. Izražava želju da se i Čista stranka prava pridruži ujedinjenju. „Skupština hrvatskih oporbenih stranaka“, Obzor, Zagreb, 29. siječnja 1903. Kako je Marjanović samo nekoliko dana ranije u Obzoru prozivao Političko društvo, može se konstatirati njegovo nezadovoljstvo Političkim društvom te da su kod njega kao pripadnika Napredne omladine aktivnog sudionika u stvaranju hrvatske građanske oporbe protiv bana Khuena, te aktivnog sudinika u Narodnom pokretu u Banovini 1903., postojale razlike u pogledima i razmišljanjima kad je bilo posrijedi pitanje načina djelovanja hrvatskog nacionalnog vodstva u Istri.

List Obzor predstavljao je otvorenu oporbu režimu bana Khuena Héderváryja i u proljeće 1903. vodio je sistematsku akciju i propagandu za održavanje skupština u Banskoj Hrvatskoj. U Obzoru su bili stari i mladi jedno. Tu su Milan Heimerl, Stjepan Radić, Milivoj Dežman, Milan Marjanović, Lav Mazzura, Hinko Krizman, Mile Miškulin, cijelo vodstvo Napredne omladine zajedno sa starima kao što su Marijan Derenčin, Šime Mazzura, Ivan Zahar, Josip Pasarić. Obzor je bio generalni stožer protukhuenovske akcije. Khuenovo redarstvo krivnju za demonstracije od 19. i 20. travnja 1903. prebacilo je na urednika i suradnike Obzora. Noću 19./20. travnja uhićeni su odgovorni urednik Josip Pasarić i glavni stalni suradnik Milan Heimerl. Tražili su i suradnika Milana Marjanovića, koji nije došao u uredništvo. Nakon nekoliko dana uhićen je i Stjepan Radić. Josip Pasarić, „Zapljene i progoni 'Obzora' pod Khuenom", Obzor, spomen-knjiga 1860-1935, Zagreb MCMXXXVI /1936./, 247; Josip Horvat, Politička povijest Hrvatske, Prvi dio, Zagreb, 1989., 222-268. 
pratio ih. Od 1900. Novi list Frana Supila, koji je također pisao o istarskim prilikama, uz Obzor je bio glasilo mlađe istarske inteligencije. Konstatacija ne aktualizira razlike između dva glasila. ${ }^{53}$

Mnogo će kritičnije pisanje dopisnika Danila u Obzoru uslijediti nakon ponovnih izbora u Tinjanu 30. ožujka, kad su narodnjaci definitivno izgubili općinsku upravu, ali u Našoj slozi javio se dopisnik koji je odobravao pisanje Istranina. Narodno glasilo piše da je riječ o mladom rodoljubu iz Istre koji preuzima odgovornost za istinitost svojih navoda. On ističe primjere samovolje nekih općinskih činovnika prema seljacima, a to je onda ove udaljavalo od Narodne stranke i približavalo "talijanašima". ${ }^{54}$ Dopisnik, između ostaloga, govori da se u hrvatskim novinama više puta pisalo o „našim stvarima”, o našem napredovanju, odnosno nazadovanju, ali da se na te „,jadikovke" nitko nije obazirao dok se nije javio Istranin u Obzoru. S njime se slažu mnogi rodoljubi u Istri. Istina je da, ako propadnemo kod kojih izbora, onda šutimo, a kad dobijemo koju općinu s par glasova većine, „gdje nema ni četiri Talijana”, onda lete brzojavi na sve strane. ${ }^{55}$ Međutim, nakon kritičkog pisanja Danila u Obzoru - o čemu je riječ dalje u tekstu - uslijedit će reakcije dopisnika Naše sloge, koje su se razlikovale od pisanja navedenog mladog rodoljuba i bile su to reakcije koje su odbacivale Danilovo pisanje.

O ponovljenim izborima u Tinjanu za prvo tijelo 30. ožujka 1903. te o Političkom društvu za Hrvate i Slovence u Istri pisao je u Obzoru spomenuti Danilo. Bio je mnogo kritičniji u osvrtima i radikalniji u stavovima u odnosu na Istranina, te je njegovo pisanje i pokrenulo reakcije. Pisanje nije uvijek prihvatljivo, pogotovo iznesene pretpostavke za nadolazeće općinske izbore. Konkretan je u pogledu osobe tinjanskog načelnika Šime Defara, te se osvrće na izbore u rujnu 1902., siječanjske izbore 1903. i na izbore održane krajem ožujka iste godine. Hrvati su naime već na nekoliko posljednjih općinskih izbora pri kraju stoljeća osvojili općinsku upravu. Na čelu općine nalazio se „inače zaslužni” Šime Defar, koji je, osim načelničke službe, obnašao i onu tajnika i blagajnika, a to mu je $\mathrm{u}$,zadnje doba bilo s opravdanih bilo neopravdanih razloga” donijelo kod tamošnjih hrvatskih općinara velik broj protivnika: „Tužili se, da ne vrši savjestno svoje trovrstne službe, da se pača previše svojim zasebnim

53 Šime Žužić, „Istra prema Hrvatskoj u razdoblju 1860.-1918.“, Obzor, spomen-knjiga 1860-1935, Zagreb, MCMXXXVI /1936./, 91-93.

Citiram ovaj primjer: „Dodjem u neki obćinski ured, razgovaram sa dotičnim g. činovnikom o našim stvarima, našim kmetovima, riečju, pretresosmo u razgovoru cijelu našu užu politiku. G. se je činovnik u svemu sa mnom slagao, osobito što se tiče seljačtva. No, najednom dodje u ured neki seljak, a dotični se g. činovnik ni pet ni šest izdere na njega: ‘Tamo za vratima stoj!' - Seljak ne reče ni bijele ni crne, nego otidje van. Od sada ga poznam kao najgorega talijanaša, dok je prije bio čestiti naš seljak. Upitam na to g. činovnika, koji je uzrok, te je tako s njim postupao, a on će meni: 'A šta, to ti je najveća marva u našoj obćini'. Pitam sada toga g. činovnika, da li je uljudno, da se tako sa seljacima postupa, osobito ako se on kao činovnik broji nekako medju inteligenciju u Istri?" "U čemu leži uzrok našemu razočaranju kod raznih izbora u Istri?", Naša sloga, Pula, 16. travnja 1903.

Na istome mjestu. 
poslovima i konačno da nemilosrdno postupa sa kmetovima." Kakva je istina - ističe dopisnik - ne namjerava je istraživati, ali je činjenica da se u posljednjem trogodištu ${ }^{56}$ vidjelo da postoji u redovima njegove stranke „neko nezadovoljstvo, neka reakcija proti načelniku". Reakciju je podupiralo Talijansko političko društvo preko svojeg agitatora „zle uspomene" Ivana Krstića, dok se sa strane načelnika, odnosno njegove stranke, nije ništa poduzelo "da se duhovi umire i narodu zadovolji”. Ogorčenje i nezadovoljstvo postiglo je vrhunac "pred kakova 4 mjeseca”, (tj. kad su raspisani novi općinski izbori za 24. i 25. rujna 1902., op. a.), i kad se pojavila vijest da Šime Defar namjerava „proti volji ogromne većine pućanstva opetovano zauzeti načelničku stolicu i opet kumulirati u svojoj osobi i službu tajnika i blagajnika". Piše Danilo da su protiv načelnikove stranke postavili nezadovoljni općinari svoje vlastite kandidate, a Talijanska stranka iz Pazina započela ih je „podupirati svim mogućim sredstvima tako, da je svaki misaoni čovjek mogao predvidjeti, da se Defar ne može i ne smije i nadalje uzdržati na načelničkoj stolici i da ga treba moralno prinuditi da odstupi". Načelnik Defar bio je uvjeren, da je irremovibilis, a Hrvatsko političko društvo sa sjedištem u Pazinu nije imalo snage ni energije da načelnika uvjeri da popusti, ili da ga prisili, kako bi odstupio. Kod izbora stranka načelnika prodrla je u sva tri tijela, tj. osvojila je većinu u sva tri tijela. Protustranka je uložila protiv izbora utok, a Namjesništvo u Trstu poništava izbore i određuje nove. Kod izbora 12., 13., 14. i 15. siječnja 1903. prodro je načelnik u trećem i prvom tijelu, tj. njegova stranka ostvaruje većinu samo $u$ dva tijela. I protiv tih izbora uložila je protustranka Šime Defara utok, a Namjesništvo ukida izbore samo u prvom tijelu i određuje ponovne za 30. ožujka. Načelnik gubi ponovne izbore za prvo tijelo, pa je tako protivnička stranka ostvarila pobjedu u dva tijela i omogućila izbor načelnika iz svojih redova. ${ }^{57}$ Dopisnik navodi da talijanske novine u povodu izbora 30. ožujka donose brzojave i članke u kojima slave izbore „kao triumf talijanske stranke u Istri. A imadu i pravo!"58 U drugom dijelu članka Danilo nastavlja pisati da se identičan

56 Legislativno razdoblje od tri godine, nakon kojeg se biralo ponovno općinsko zastupstvo.

Dok je L'Istria pisala u povodu siječanjskih izbora 1903. da je u drugom tijelu pobijedila „lista italiana“, sada krajem ožujka piše da je u prvom tijelu pobijedila „lista istriana“ s dva glasa razlike („dei quali 37 votarono per la lista istriana, 35 per la croata“). „Cronaca. La vittoria di Antignana.“, L'Istria, Parenzo, 4. aprile 1903.

Kao primjer navodim pisanje - meni dostupnih - talijanskih novina Il Giornaletto di Pola. One pišu s gledišta interesa vladajućih talijanskih građanskih liberala. Glasilo izvještava prvi dan neposredno nakon izbora, spominjući tinjansku općinu kao panslavističko uporište: „I lettori ricorderanno le elezioni d'Antignana che riuscite materialmente sfavorevoli al partito istriano che si era ribellato all'amministrazione croata del podestà Defar, furono moralmente una vittoria del partito stesso, poichè solo in seguito ai soprusi della commissione in tutti e tre i corpi riuscirono eletti i candidati croati. La luogotenenza annullò l'atto elettorale ed indisse nuove elezioni nelle quali riusci nel terzo e primo corpo vincitore il partito croato e nel secondo il partito istriano. Però anche tale risultato non fu ottenuto senza illegalità, tanto è vero che la luogotenenza annullava le elezioni del primo corpo ed indiceva nuove elezioni per ieri. Un telegramma giuntoci ieri sera ci annuncia la vittoria degli istriani, la quale segna la caduta definitiva della amministrazione croata nel Comune di An- 
slučaj u Tinjanu dogodio prije kakvih deset godina u Općini Veprinac, u kojoj čovjek sa svijećom u ruci ne bi mogao naći živog Talijana. I tamo su bili općinari nezadovoljni ondašnjim vlastodršcima te su ih odstranili i postavili na čelo općine ljude, „rodom doduše Hrvate, ali inače nestalne u svojim političkim nazorima”. Rezultat je bio takav da je „hrvatska obćina Veprinac prešla u ruke najžešćih neprijatelja svega, što hrvatskim diše", u ruke ljudi koji glasuju za čovjeka kao što je Felice Bennati i koji općinskim sredstvima podupiru talijanske institucije u pokrajini kao što je primjerice talijanska gimnazija u Pazinu ${ }^{59}$ ili Lega Nazionale.$^{60}$ Svi pokušaji Narodne stranke da pridobije općinu bili su uzaludni. Nakon Veprinca pada Lovran, za Lovranom Mošćenice, a u nedalekoj budućnosti ista sudbina prijeti Općini VoloskoOpatija. Tijekom „10 godina podlegnuše na taj način 3 tvrdjave hrvatstva u kršnoj Liburniji”. Dok se ta „evolucija” razvijala na „Kvarnerskoj obali, zadaše Talijani zadnji udarac hrvatskim obćinama Višnjan i Momjan", koje su također došle u njihove ruke. Sad je došo na red Tinjan, za njim dolazi Boljun, ${ }^{61}$ onda Buzet itd. Iz ovih kratkih navoda razvidno je - ističe dopisnik - da hrvatska narodna stvar u Istri svakim danom nazaduje. Ističe da će svaki misaoni čitalac postaviti pitanje koji su uzroci tog nazadovanja. Danilo daje odgovor. Do otprilike godine dana spadala je Istra pod djelokrug „revnog” Političkog društva Edinost iz Trsta, a lanjske godine smatrali su naši istarski prvaci potrebnim odvojiti se od spomenutog društva da mu olakšaju i onako tešku borbu što je vodi u samom Trstu i okolici te da utemelje mlado društvo koje bi trebalo "oživiti Istru”. Svaki je Hrvat odobravao taj korak istarskih prvaka s oduševljenjem videći u njemu znak napretka: „Nu, žalibože, prevarismo se." Političko društvo za Hrvate i Slovence u Istri „,spava tvrdi san nedužnoga!" Od njegova utemeljenja do danas nije se o njemu "ništa ni čulo ni pisalo". Umjesto da započne svoj rad, da razvije svoj program, da imenuje pododbore i pouzdanike $u$ pojedinim općinama, mjesto da se organizira i započne „realan rad” - ono „spava tvrd san". Nastavlja dopisnik da je izborna borba i agitacija u pojedinim općinama i kotarima prepuštena pojedincima "koji rade i ne rade po svojoj glavi”, a Političko društvo - umjesto da se kao predstavnik hrvatskog naroda u Istri upusti u borbu, da savjetuje, izdaje naloge i radi - „spava prekriženih ruku”. To je „rak-rana” zbog koje trpi čitava Istra i cijeli hrvatski narod u pokrajini i u tome moramo pronalaziti razloge poraza u Općini Tinjan. Političko društvo kojem je sjedište u Pazinu moralo

tignana, ritenuto fino a pochi mesi ta rocca inespugnabile dei panslavisti; per cui la giornata di ieri viene considerata di importanza eccezionale. I croati riportarono voti 35 e gli istriani voti 37." „Notiziario cittadino. L'epilogo delle elezioni di Antignana. Una vittoria istriana.", Il Giornaletto di Pola, Pola, 31. marzo 1903.

Talijansku realnu gimnaziju u Pazinu Hrvati su nazivali „prkos-gimnazijom“ zbog ranije utemeljene hrvatske gimnazije. B. Milanović, Hrvatski narodni preporod u Istri, II, 380-381.

O tom društvu: Ante Cukrov, „Pro Patria i Lega Nazionale u sustavu istarskoga školstva“, Nova Istra, III, IX, 2, 1998., 243-257. 
je predvidjeti što će se dogoditi u Tinjanu, njemu je pred očima morao stajati poraz u Općini Veprinac i njegove kasnije posljedice. Ono je moralo energično nastupiti u izbornu borbu i prinuditi načelnika Defara kako bi odstupio. Ono je moralo žrtvovati osobu načelnika sveopćoj stvari, a ako ovaj ne bi htio odstupiti, onda je bila „sveta dužnost" Odbora Političkog društva da se sporazumi s nezadovoljnicima i da ih podupre. Nikako se nije smjelo dopustiti da se Talijani umiješaju u izbore, da budu izabrani ljudi nestalnih političkih nazora, koji će danas-sutra, poput Veprinčana, biti naši najljući neprijatelji - hrvatski janičari. Na kraju svojeg pisanja Danilo otvoreno izražava zabrinutost i pesimizam. Izabrani u općinsko zastupstvo svi će biti Hrvati, pa ipak talijanske novine proglašavaju izborne rezultate kao vittoria nazionale, $\mathrm{tj}$. narodnom pobjedom; „dao Bog da bih lagao". Za koju će godinu nekadašnja hrvatska općina u Tinjanu „votirati debele svote za talijansku gimnaziju u Pazinu”, a Tinjanci će slaviti pobjedu čovjeka kao što je F. Bennati. Slično „komešanje” primjećuje se i u nekim drugim našim općinama, primjerice u Boljunu ${ }^{62}$ i Buzetu, a budu li Političko društvo i oni koji u njemu „,vode glavnu rieč" provodili i dalje takvu politiku, „onda jao si ga nama”. Onda je uzalud graditi škole i zvati braću Hrvate u pomoć, „kad nam naš narodni posjed danomice ispod nogu bježi". Dopisnik konstatira da su prilike takve "da se ne može Bog zna kakvog napredka očekivati", ali se zato barem od naših prvaka može zahtijevati „da bdiju nad dosadašnjim našim pozicijama, da barem njih ne izgubimo".63

Danilo je svojim pisanjem blizak Istraninu. Kritičniji, i on je nezadovoljan djelovanjem vodstva nacionalnog pokreta. Smatram da i na njega djeluju svekolika zbivanja u Banskoj Hrvatskoj na radikalizaciji promišljanja i stavova kad je bilo posrijedi djelovanje vodstva pokreta u Istri. ${ }^{64}$

Istog dana kad Obzor objavljuje Danilovo pisanje osvrtala se na izbore u Tinjanu i Naša sloga. Na osnovi njezina navođenja može se zaključiti da je načelnik Defar ipak bio pod nekakvim pritiskom da odustane od kandidature ili je i sam počeo o tome razmišljati neposredno pred izbore 30. ožujka. Glasilo naglašava da je općinski glavar prije izbora odlučio otkloniti tu svoju čast. Proizlazi da Obzorov dopisnik Danilo možda nije za to znao ili da je odstupanje načelnika došlo prekasno, jer se mišljenje i raspoloženje općinara već očito bilo formiralo: „Novi izbor za I. tielo bio je odredjen za 30. marča. U borbu dale su se iste stranke, kao kod zadnjeg izbora, jedna naime, koja je htjela uzdržati predaje dosadanjeg obćinskog zastupstva, ako i ne pod istim obćinskim glavarom, pošto je bio odlučio odkloniti na svaki način tu čast, a druga, za koju se baš još ne znade što hoće i kani. Ogromna većina naime ove

\section{U tekstu piše: „Boljinu“.}

63

Danilo, „Uskrsna Jabuka. Iz srednje Istre, 1. travnja.“, Obzor, Zagreb, 2. travnja 1903.

64

Dopisnik Danilo piše neposredno nakon jednog značajnog događaja, nakon demonstracija u Zagrebu krajem ožujka zbog postavljenog mađarskog natpisa na zgradi državnih željeznica, a što se, po Obzorovu pisanju, kosilo s paragrafom 57. Hrvatsko-ugarske nagodbe. J. Pasarić, 247. 
potonje stranke o talijanstvu neće da čuje, ali ipak postavljena je na noge i uzdržana od pazinskih renegata." ${ }^{\prime \prime 5}$

Smatram dvojbenim podatak koji navodi Naša sloga da je Hrvatska stranka 30. ožujka izgubila s dva glasa razlike u prvom izbornom tijelu, ${ }^{66}$ ako se usporedi sa siječanjskim rezultatima u istom tijelu koji su bili poništeni, kad je Hrvatska stranka ostvarila pobjedu s dva glasa većine, kako navodi u Obzoru Istranin, tj. M. Marjanović. Mala razlika od dva glasa pokazatelj je političkih napetosti i sukobljavanja u općini, gdje su suprotstavljene strane u prvom tijelu gotovo izjednačene.

Nije jasno zašto dopisnik Danilo pesimistično gleda na Općinu Volosko-Opatiju, gdje je Narodna stranka ostvarivala dobre izborne rezultate, pa je tako prošle 1902. godine ostvarila novu izbornu pobjedu u svim trima izbornim tijelima. I ti su izbori bili burni i dinamični, a Ivan Krstić zajedno s pristalicama - potpomaganim od Talijanske stranke - očekivali su pobjedu. ${ }^{67}$

Pesimizam nije bio utemeljen i s obzirom na mjesnu Općinu Buzet, jer je i tu Narodna stranka 1902. ostvarila novu izbornu pobjedu. Ali se pesimizam u vezi s Općinom Buzet izrazio i kod istarskih narodnjaka; zbog odlaska odvjetnika Matka Trinajstića iz Buzeta u Volosko. Prelazak Trinajstića narodnjacima morao je predstavljati ponajprije pitanje organizacije nacionalnoga rada i pitanje vođenja nacionalnih organizacija. Ne samo da je Trinajstić izabran za općinskoga načelnika već je bio i gospodarski i kulturni djelatnik, sudjelovao je u vođenju gospodarskih i kulturnih institucija te je kod nacionalnog vodstva razumljiva težnja za njegovim nadomještanjem. Zabrinutost je razumljiva jer su odvjetnici u političkoj stvarnosti predstavljali stožer u nekome mjestu ili općini oko kojega se organizirao i pokretao nacionalno-politički rad. Međutim u mjesnoj Općini Buzet utjecaj narodnjaka bio je učvršćen. Vidi se to po rezultatima održanih općinskih izbora - 1894. i 1897. - pobjedu odnosi Narodna stranka, koja pobjeđuje i 1902. i 1906. Matko Trinajstić izabran je za načelnika 1894. i 1897., Antun Klarić 1902., a Fran Flego 1906. ${ }^{68}$

„Izbori u Tinjanu“, Naša sloga, Pula, 2. travnja 1903.;

Na istome mjestu.
}

Službeno općina Volosko-Opatija nosi taj naziv od 1910. Hrvatski narodnjaci prvi put odnose pobjedu na općinskim izborima u ožujku 1895. Općina Volosko-Opatija postat će primjerom dobro organizirane i uzorno vođene narodnjačke općine. Svojom gospodarskom snagom djelovala je na političko okupljanje Hrvata s obiju strana Učke. Dugogodišnji njezin načelnik bio je Andrija Stanger. Goran Crnković, „,Borba narodnjačke općine Volosko-Opatija za hrvatsko školstvo“, Problemi sjevernog Jadrana, 5, 1985., 149-151; Ž. Klaić, „Nacionalni pokret istarskih Hrvata i Slovenaca na prijelomu XIX. u XX.", 62-63.

Petar Strčić, „Četiri krčka advokata u političkom životu Istre i Kvarnerskih otoka“, Odvjetnik, 9, 1968., 239-240; Stjepan Kraljević, „Vodogradnje na Buzeštini 1861. do 1914. godine“, Buzetski zbornik, 7-8, 1984., 251-259; Božo Jakovljević, „Općina Buzet u zapisnicima sjednica općinskog zastupstva od 1894. do 1911. godine“, Buzetski zbornik, 20, 1995., 33-50; B. Milanović, Hrvatski narodni preporod u Istri, II, 236-237; Ž. Klaić, „Nacionalni pokret istarskih Hrvata i Slovenaca na prijelomu XIX. u XX.", $58-60$. 
Kad je riječ o Općini Veprinac, gdje su pristalice Ivana Krstića uz pomoć Talijanske liberalne stranke obnašali vlast $\mathrm{u}$ općini, onda Narodni list u povodu općinskih izbora krajem studenoga 1902. piše o nekim naznakama mogućih promjena. ${ }^{69} \mathrm{Hr}-$ vatski narodnjaci pobjeđuju na izborima u Veprincu 1906./1907., a glavarom općine imenovan je Ivan Bačić. ${ }^{70}$

Narodna stranka nakon po nju poraznih tinjanskih izbora odnosi pobjede $\mathrm{u}$ Žminju i Boljunu da bi pri kraju 1903. odnijela pobjedu u Općini Roč, gdje do tada nije nikad držala tamošnju općinsku upravu. Može se govoriti o tome da je pobjeda narodnjaka u Roču bila iznenađenje za talijanske liberale, kao što je poraz Narodne stranke u Tinjanu primljen s iznenađenjem na hrvatskoj strani. ${ }^{71}$

Primjedbe da je Političko društvo za Hrvate i Slovence u Istri bilo neaktivno u povodu općinskih izbora u Tinjanu i da njegovi voditelji nisu bili uključeni u te izbore nisu točne. Preciznije je navesti da se o aktivnosti Političkog društva nije sve iznosilo u javnost. Može to posvjedočiti obavijest u Našoj slozi o sjednici Odbora Političkog društva održanoj 23. travnja 1903. Obavijest je dosta kratka i sažeta ako se usporedi s tekstom Spinčićeva zapisa o istoj sjednici Odbora. U obavijesti stoji da se na sjednici raspravljalo o izborima u Tinjanu i o pisanju Obzora od 2. travnja. Odbor je preporučio svim novinama izvan Istre da urednici budu oprezniji kod primanja "ovakvih vijesti" kako ne bi time više štetili nego koristili. U obavijesti u Našoj slozi kratko se ističe činjenica imenovanja društvenih povjerenika i predstojeći općinski izbori u Žminju i Boljunu te se spominje rasprava na sjednici u povodu dekreta Kongregacije obreda u Rimu iz 1898. u vezi sa staroslavenskim jezikom što ga je objavio novoimenovani tršćansko-koparski biskup Franz Xaver Nagl. ${ }^{72}$

Spinčićev zapis o sjednici Odbora govori o tinjanskim izborima te o drugim izborima koji su se trebali održati, kao i o drugim pitanjima kojima je vodstvo Po-

$\overline{69}$ U izborima za treće tijelo, u koje je bilo uneseno 400 izbornika, konstatira se velika razlika u korist protivnika, ali i velika apstinencija. Za „Talijane i talijanaše” glasovao je 131 izbornik, a za hrvatske narodnjake glasovao je 61 izbornik. Narodni list ističe da je taj broj glasova - 61 - značajan za hrvatske narodnjake jer oni na posljednjih nekoliko izbora nisu nastupili ni za treće ni za drugo tijelo. Svega s nekoliko glasova razlike u drugom tijelu odnose pobjedu pristalice Ivana Krstića, a u prvom tijelu također s nekoliko glasova razlike odnose pobjedu istarski narodnjaci. Optužuje se za izdaju trojicu izbornika u drugom tijelu koji su na dan izbora 29. studenoga otputovali, iako su prethodnoga dana obećali da će glasovati s Narodnom strankom. Od njih troje dvoje su se u Rijeci bili sastali s Ivanom Krstićem. Glasilo smatra pozitivnim izbor jednoga od općinskih savjetnika koji je dolazio iz redova Narodne stranke. List piše kako je Felice Bennati predsjednik Istarskoga političkog društva, neposredno prije izbora donio vreću novca kojim se kupovalo glasove. Piše dopisnik i da je dotični isticao na skupštini Istarskoga političkog društva u Trstu 12. prosinca kako je kod tih općinskih izbora u Veprincu pobjedu odnijela Talijanska stranka, ali da kod pripremanja nekih izbora Talijani redovito govore i pišu da se bore „per il partito istriano". ,"Veprinački obćinski izbori", , ,Veprinačke izborne iskrice”, Narodni list, 4. prosinca 1902.; „Izbor načelnika obćine Veprinac", „Talijanska pobjeda va Veprincu”, Narodni list, 18. prosinca 1902.

B. Milanović, Hrvatski narodni preporod u Istri, II, 269.

71 Ž. Klaić, „Nacionalni pokret istarskih Hrvata i Slovenaca na prijelomu XIX. u XX.“, 67-76.

72

„Političko družtvo za Hrvate i Slovence za Istru“, Naša sloga, Pula, 7. svibnja 1903. 
litičkog društva bilo zaokupljeno. Između ostalog, Spinčić precizira djelovanje Krstića i njegovih pristaša. Prema Spinčićevu navođenju, na čelu je stranke protivnika Šime Defara Venceslav Križmanić, koji je igrao dvoličnu ulogu. On je s Krstićem i „talijanašima"73 držao skupštine u Sv. Petru u Šumi. U nazočnosti Dinka Trinajsti-

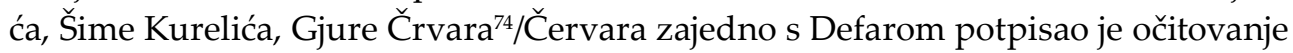
prema kojem su se Defar i on pomirili, a onda je drugi dan molio da se to ne objavi. Križmanić je prije ponovnog izbora za prvo tijelo obećao da će kao član izborne komisije s Narodnom strankom glasovati, ali je od toga odustao. Ipak, treba ga uzimati u obzir da ga se vrati na pravi put. Treba pokušati zastupnike druge stranke na lijep način pridobiti. Svakako da je i Defar kriv, ali su i drugi razlozi doveli do izbornog neuspjeha, kao što su lakovjernost naroda i zaduženost kod Talijana. Predstavnici Političkog društva D. Trinajstić, Š. Kurelić, Gj. Červar učinili su sve moguće i bili su čitavo vrijeme u kontaktu s Tinjanom. ${ }^{75}$

Ono o čemu se na osnovi Spinčićeva zapisa može promišljati jest to što stranačka organizacija istarskih narodnjaka u Tinjanu, ali ni drugdje još nije utvrđena ni učvršćena. ${ }^{76}$ Upućuju na to sami sukobi unutar hrvatskih izbornih redova u Tinjanu, sukobi koji se nisu mogli kontrolirati ili spriječiti. A s druge strane sukobi ukazuju na diferencijaciju u redovima tinjanskih općinara. Neizgrađenost stranačke organizacije u tom kratkom vremenu po osnivanju Političkog društva pogodovala je situaciji u kojoj su se sukobi mogli pojaviti i razviti. Međutim, sukobljavanje nije moglo biti odlučujuće i jedino objašnjenje poraza Narodne stranke u Tinjanu.

Političko društvo za Hrvate i Slovence u Istri nakon utemeljenja u svibnju 1902. trebalo je utvrditi svoju organizaciju na terenu. Do početka 1903., kad dopisnik Istranin piše u Obzoru, ili kad svojim pisanjem u povodu izbora u Tinjanu krajem ožujka 1903. istupa Obzorov dopisnik Danilo, prošlo je nešto više od pola godine, ne više od godine dana, a to je period koji i nije tako dug da bi se mogla izgraditi neka čvrsta narodna organizacija na terenu. Sâm „Popis” od šezdesetak društvenih članova jest osnova za izgradnju organizacije. ${ }^{77}$ Međutim, problem sa stručnim osobama koje su

73 Spinčić je ovdje u zapisu naveo velikim slovom 'Talijanaši', premda često piše i 'talijanaši'. preporučio osobito „zapt i posluh", tj. potrebu discipline i posluha u redovima Narodne stranke. Očito da je „zapt i posluh" smatrao potrebnim zbog ustanovljenja čvrste i jedinstvene stranačke organizacije, kojom će se lakše ostvarivati ciljevi narodnog pokreta. „Političko družtvo za Hrvate i Slovence u Istri“", Naša sloga, Pula, 12. svibnja 1902.; Već na početku svoje aktivnosti Političko društvo susreće se s problemom utvrđivanja organizacije na terenu, pa je tako postojao problem s imenovanjem društvenih povjerenika. D. Trinajstić u pismu V. Spinčiću 11. listopada 1902. pritužuje se povodom toga: „Od svih političkih odbornika još nije niti jedan predložio povjerenike iz svog kotara. Pak da ćemo napried uz takve odnošaje?!“ Ž. Klaić, „Nacionalni pokret istarskih Hrvata i Slovenaca na prijelomu XIX. u XX.", 59. 
u nekome mjestu ili općini trebale voditi aktivnost stranke, pogotovo pomanjkanje odvjetnika, ključnih pojedinaca u vođenju javne djelatnosti, očito je postojao i nije se mogao tako brzo riješiti. Problem s vođenjem i pomanjkanjem kadra pogotovo je postojao i ranijih desetljeća, zbog čega su se nacionalni prvaci i morali oslanjati na istaknute pojedince iz seoskih redova ili na istaknute svećenike, kao i na druge istaknute pojedince. Vrijeme prijeloma stoljeća ipak je vrijeme kad dolazi do smjene $\mathrm{u}$ vodstvu nacionalnog pokreta, kad će svjetovna inteligencija postupno preuzimati pozicije i kad će zamjenjivati duhovnu inteligenciju. Ali pomanjkanje kadra, onih koji će u nekoj sredini predvoditi nacionalno-politički rad, kao problem i dalje postoji. Materijalni su uvjeti svakako morali utjecati na formiranje i utvrđivanje političke organizacije.

Stranačko vodstvo teško da je moglo kontrolirati neke slučajeve samovolje na terenu, neke slučajeve pogrešnog postupanja prema seljacima, upravo zbog toga što ni struktura stranačke organizacije još nije izgrađena ni učvršćena da bi u takvim slučajevima mogla reagirati. Teško je govoriti o učestalim primjerima samovolje, premda takve primjere treba uzimati u obzir kad se želi sagledati postojeće stanje. Smatram da se naglašavanjem takvih primjera kao i to da su takvi primjeri utjecali na izborne rezultate ne može smatrati odlučujućim. Sadržaj sukobljavanja koji je znatnije morao potencirati nezadovoljstvo tinjanskih općinara - pa time i utjecati na izborne rezultate - morao se odnositi na pritužbu da Defar namjerava protiv volje većine općinara „opetovano zauzeti načelničku stolicu i opet kumulirati u svojoj osobi i službu tajnika i blagajnika". Treba li, kad je riječ o izbornim rezultatima, uzeti u obzir i druge čimbenike, kao što su gospodarsko-socijalni, ili su u pozadini zbivanja mogle postojati idejne razlike? ${ }^{78}$

upućuje Kotarskom poglavarstvu u Pazinu „Prijavu“ s navedenim sastavom glavnog društvenog odbora te sa zamjenicima odbornika. Uz „Prijavu“ je priložen i „Popis članova prijavljenih 'Političkom društvu za Hrvate i Slovence u Istri' - u Pazinu“. Navedenih je njih šezdeset i dvoje. Između ostalih, jedan od zamjenika odbornika bio je i Šime Defar. On se nalazi i na „Popisu članova“ kao i njegov brat Ivan Defar. Ž. Klaić, „Nacionalni pokret istarskih Hrvata i Slovenaca na prijelomu XIX. u XX.", 53-54.

U političkom životu Istre na kraju XIX. i početkom XX. stoljeća javljaju se i nova idejna kretanja kao posljedica novih idejnih previranja u Monarhiji, ali i u ostaloj Europi. Odnos prema narodno-liberalnoj i kršćansko-socijalnoj struji unutar Narodne stranke, odnos prema katoličkom i socijalističkom pokretu posebno zaokuplja vodstvo istarskih narodnjaka, i to u smislu čuvanja jedinstva stranke i nacionalnih redova. Krajem XIX. i početkom XX. stoljeća na slabljenje pozicija istarskih narodnjaka utjecat će spomenuti istrijanski pokret, koji je novčano potpomagala Talijanska liberalna stranka. U smislu prevladavanja idejnih sukoba i čuvanja jedinstva stranke često istupaju Matko Laginja, Matko Mandić, Vjekoslav Spinčić, Dinko Trinajstić i drugi prvaci. Vodstvo Narodne stranke, uočavajući idejne razlike i sukobe, pozivat će na jedinstvo nacionalnih redova i u tom smislu nastupati na javnim sastancima i skupštinama, bez obzira na to što se nedoumice i krizni trenuci javljaju i između samih voditelja. Takav nastup nije bio samo običan politički pragmatizam. Između ostaloga, bilo je to iskustvo dugogodišnjega upornoga legitimnog rada, ali i predosjećaj kriznih nadolazećih vremena, vremena izraženih europskih suprotnosti s nejasnim ishodima i rezultatima, 
Kritičnost Obzorovih dopisnika upućena nacionalnom vodstvu javlja se pod utjecajem previranja u Banovini, premda se u njihovu pisanju to direktno ne primjećuje. Ali proces izgradnje i utvrđivanja političke organizacije traje, kao što se odvijao i proces izgradnje gospodarske organizacije te proces razvoja kulturnih organizacija. Ta aktivnost narodnjaka odvijala se niz godina - još u okviru tršćanske Edinosti daleko prije kritičkog nastupa Istranina i Danila, a i nakon njih, u mjesecima koji će uslijediti, javit će se novi kritičari svojim istupima. Utemeljenjem i djelovanjem političke organizacije, utemeljenjem i djelovanjem gospodarske organizacije, razvojem raznih kulturnih institucija i demokratizacijom izbornog zakonodavstva za bečki parlament na osnovi kojeg je Narodna stranka 1907. ostvarila uspjeh, problemi u razvoju nacionalnog pokreta na prijelomu stoljeća - kako je već istaknuto - bili su prevladani.

Primjedbe upućene vodstvu Političkog društva za Hrvate i Slovence u Istri, na čijem se čelu nalazio Vjekoslav Spinčić, neće se odnositi samo na primjer rezultatā nekih općinskih izbora. Primjedbe su se odnosile i na razna druga pitanja. Primjerice, na skupštini Političkog društva u Pazinu 7. travnja 1904. Spinčić je navodio primjedbe da nema dovoljno odvjetnika i odvjetničkih kandidata koji bi potpomagali narod, da glasilo stranke Naša sloga nema u Puli, mjestu gdje izlazi, stalnog urednika, ${ }^{79}$ a isticao je i to da postoje određene poteškoće s kojima se društveno vodstvo susreće pri utvrđivanju političke organizacije na terenu. Naglašavao je da se društva poput Političkog društva za Hrvate i Slovence $u$ Istri ne utemeljuju da bi u njima radili pojedinci već mnogi udruženim snagama. Na svima je - a najviše na mlađima - da društvo ostvari svrhu. Neka se mlađi učlane u društvo, neka oni utemeljuju mjesne, općinske te kotarske odbore; neka oni budu birani u te odbore i neka u njima aktivno sudjeluju; neka se dadu birati u glavni odbor i neka dolaze na sjednice; neka drže sastanke i održavaju skupštine. Neka mlađi sa svojih prostora izvješćuju glavni odbor kako bi on mogao ispuniti svoju zadaću; neka oni pišu u glavni organ stranke i neka ne zamjere ako se nešto s razlogom ne tiska te neka stupe u kolo starijih i zamijene ih gdje treba. Vjekoslav Spinčić na skupštini je odbacivao kritike da Političko društvo ne djeluje ili da se ne rješavaju postavljena pitanja. On tako nije prihvaćao primjedbe da narodno vodstvo ne održava javne sastanke ili da ne djeluje u povodu općinskih ili drugih izbora. On će na skupštini u Pazinu navoditi niz nacionalnih prvaka i broj javnih sastanaka i skupština koje su oni održali. ${ }^{80}$

a zalažući se i pozivajući na jedinstvo stranke i nacionalnih redova želi se očuvati teško stečene pozicije $u$ istarskoj pokrajini.

O pitanju uredništva: Ž. Klaić, „Matko Mandić i pitanje Naše sloge”, 67-80.

80

"Glavna skupština političkog družtva za Hrvate u i Slovence Istre“, Naša sloga, Pula, 14. travnja 1904. 


\section{Dopisnik Naše sloge Novi Jornaleto protiv Obzorova Danila}

Premda glasilo Narodne stranke Naša sloga objavljuje dopis mladog rodoljuba koji podržava Istranina u Obzoru, ipak se reakcija njezinih dopisnika svodila na odbacivanje pisanja Obzorova Danila. Svojim se oštrim reagiranjem u Našoj slozi ističe Novi Jornaleto. On priznaje tendencije monopolizacije u hrvatskoj politici u Istri, ali ne prihvaća tumačenje kako se radi o slabljenju hrvatskih pozicija već govori suprotno, o napretku, i kao činjenice s tim u vezi ističe gospodarski i prosvjetni čimbenik. Pritom upućuje kritiku Zagrebu i Obzoru kao zagrebačkom glasilu: „Dakle nije baš da nazadujemo, kako je pred malo dana pisao šiòr Danilo u zagrebačkom Obzoru, nego, kako smo se probudili i razvikali u kratko vrieme, htjeli bismo imati sve najedanput, pa nas se grozno dojmi malo 'mrzle vode', što nas poškropi u realnom političkom životu. Ima zla, žalibože; ima i nada i hira pače i monopoliziranje u hrvatskoj politici u Istri, a izbori u Tinjanu su dokaz za sve to: ali zar nije to plod zagrebačke škole? Od krova se ne počima graditi kuću, a hrvatski političari su žalibože svuda uveli tu metodu, dočim su se malo ili ništa brinuli za čvrst temelj na kojem bi se dalo zidati. A temelj dobre, demokratične politike nalazi se u puku: ovomu treba obezbiediti gospodarstveni i duševni napredak, treba ga uzgojiti u pojimanju i razlikovanju dobra i zla, treba ga podučiti o njegovoj moći. Što će nam tobože 'hrvatska' obćina, ako kmet mora za svoje potrebe uteći se Krnjelu ${ }^{81}$ ili talijanašu? Treba najprije skrbiti, da se puku može dati sve što rabi, iz hrvatskih ruku! A u tom pogledu neima nazadka, nego neka se Obzor i njegov Danilo tješe, imade hvala Bogu, napredka. Broj posujilnica i konsumnih društava raste svakim danom, traženje kredita je prilično olahkoćeno, poljodjelstvo se diže, a kako smo jur javili i što se potvrdjuje na drugom mjestu, ustanovila se i Gospodarska Sveza za Istru koja će u kratko započeti djelovanjem. ${ }^{82}$ Zar to nije napredak? A uz to s druge strane škole se proširuju, nove se ustrajaju. Kad bude narodu dobro u ta dva pravca, neće biti moguća iznenadjenja, kao ono u Tinjanu. Sa zaduženim neukim pukom, s ljudima, koji su više tudji nego svoji, a ni sami neznaju, što su, - težko je biti političke bitke. To bi najbolje morali znati gospoda oko Obzora, kojega patroni, bili biskupi, kanonici, profesori ili bankiri, sve, brajne, zlatom podkovani, su se bavili uvjek svačim drugim nego li podizanjem i prosvjetljivanjem puka. Amo jeftinog kredita, gospodo u Zagrebu, a ne po osam postotka, amo podpore za škole, amo dobrih ljudi i žarke ljubavi - pa se ne ćete tužiti na Istrijance.

$\overline{81}$ O Krnjelima u Istri, doseljenicima iz pokrajine Karnije (Carnia) na sjeveru Italije: Miroslav Bertoša, „Bilješke i komentari“: Carlo De Franceschi, Uspomene, Pula - Rijeka, 1989., 223-225; Just Ivetac, „Rasadnik istarskih Karnjela“, Istarska Danica 2001., Pazin, 2000., 108-115; isti, Furlanski i karnjelski zrmani, Pazin, 2003.

82 Usput: Željko Klaić, „Novčane prilike Gospodarske sveze za Istru (1918.-1924.)“, Vjesnik Istarskog arhiva, 4-5, 1998., 89-90. 
Inače, neka govori tko što hoće, pobjeda 'talijanske' (?), gdje Talijana neima, kako ih neima ni u Tinjanu, ni u Veprincu, ni u Mošćenicama, ni u Boljunu, ni drugdje, nisu baš tako zatorne za nas, koji nismo vični objesiti na veliko zvono svaki korak što ga činimo. Isti ljudi, koji su kao Hrvati izabrali Hrvate prije - sada biraju druge (pa baš njeke i od onih, koji su i pod hrvatskom firmom bili izabrani), hoteć se suprotstaviti samovolji pojedinaca. A što su ti ljudi zlorabljeni od Talijana, koji s njima moraju govoriti i njima pisati u hrvatskom jeziku, to je već slaba svjedočba za tobožnje 'talijanstvo', dočim je s druge strane uputa za prvake hrvatske stranke, kako se nesmi graditi kule u zraku, nego kako treba puk utvrdjivati u poštenju i narodnoj sviesti. Ruku na prsa svi, pa i 'Obzorov Danilo te se pitajmo: 'kako smo do sada odgovarali zadaći?' Odgovor ima glasiti: 'griješilo se mnogo, jer se je zabasalo; iz početka, dok je doba!"'>83

Drugi dopisnik u Našoj slozi navodi kako je Tinjan ,,jedna od najčišćih naših narodnih obćina. Tamo imade malo Talijanaša ili Krnjela, koji su znali okoristiti se neslogom u hrvatskom taboru. Oni sami nemogu tamo absolutno ništa. Njim je došao u prilog sukob izmedju hrvatskih muževa one obćine i oni podpomogoše srušiti dosadašnju upravu one obćine. U Tinjanu nije se radilo, da se sruši hrvatsku upravu i da se ju pak zamjeni talijanskom. To uvidjaju i sami naši dušmani, dotično njihovi listovi. Nijedan bo nije se do sada usudio uztvrditi, da je pobjedila talijanska stranka, već buncaju samo o pobjedi naših istomišljenika il o pobjedi istrijanske stranke, kao da nije i hrvatska stranka istrijanska. U prvom tielu naime izabrana su samo dvojica, koje se nemože brojiti medju naše, dočim šestorica njih bijaše jur u prvašnjem zastupstvu. Jedan od te nove stranke izjavio je nedavno, da se talijanaši varaju ako misle, da je stranka protivna sadašnjoj upravi odnosno da je talijanska stranka. Njegova da će stranka javno dokazati, da nije ništa manje hrvatska nego li je ona, proti kojoj se je borio. Mi ga čekamo na djelu i jao si ga njemu, ako je prevario sve one, koji govore i ćute hrvatski, a koji mu pomogoše srušit sadašnje upravitelje. Tamno lice tih izbora nalazimo u tom, što se nije znalo ili htjelo energičnije predusresti razdoru medju našimi uplivnijimi muževi u onoj obćini. Tamo se je moralo pokušati sve moguće, da se odstrani razloge ili povod tomu razdoru, te da se povadjenu braću na vrieme izmiri, pa stojalo to bilo kakvih žrtava. Novu stranku u Tinjanu čekamo sada na djelu i budu li se njezini prvaci držali gori navedene izjave, baciti ćemo koprenu zaboravnosti na sve nemile dogodjaje u onoj obćini od prošloga mjeseca marča. Od nove većine u obćinskom zastupstvu očekujemo, da će u narodnom pogledu držati visoko narodnu zastavu a što se tiče uprave, da će nastojati, da nebude gora od dosadašnje. Njezini prvaci imati će da dokažu, da nisu znali samo kritizirati, već da znadu i raditi pošteno, nesebično i rodoljubno. Mi ih čekamo, dakle na djelo!"'84

\footnotetext{
$\overline{83}$ Novi Jornaleto, „Domaće stvari“, Naša sloga, Pula, 9. travnja 1903. 
I jedan i drugi dopisnik naglasili su sukobe unutar hrvatskih redova kao onaj momenat koji je doveo do izbornih rezultata. Pogotovo je drugi istaknuo - nešto slično kao i Danilo u Obzoru - da se moralo energično nastupiti u sprječavanju razdora među utjecajnim muževima u općini, odstraniti razloge sukoba na vrijeme bez obzira koliko to stajalo žrtava. Konstatacija upućuje na promišljanje o tome da stranačka organizacija u Tinjanu još nije bila utvrđena. Međutim, ni jedan ni drugi dopisnik ne iznosi radikalan i pesimističan stav da je zbog izbornih rezultata riječ o propadanju hrvatstva ili o nazadovanju nacionalnog pokreta.

U Istri na kraju XIX. i početkom XX. stoljeća traje proces uspostavljanja zadružnih organizacija, kreditnih zadruga, važnih posujilnica, a zatim i gospodarsko-potrošačkih zadruga. Voditelji narodnog pokreta u Istri - kojima je uspostava kreditnih zadruga jedan od primarnih ciljeva - idu za tim da seljaštvo treba osloboditi zaduženosti. Proces uspostave posujilnica i njihov rad nije suvremenicima morao biti uočljiv, a i rezultati dugogodišnjega gospodarskog djelovanja do kojih se dolazilo sporo su se ostvarivali. Činjenica gospodarskog napretka zadruga koji se vidi iz podataka godišnjih zadružnih obračuna - broj zadrugara, zadružni dijelovi, zajmovi, vraćen novac, čisti dobitak, novčani promet, štedni ulozi - podaci su poznati u prvom redu onima koji su se bavili zadružnim radom. Dopisnici Obzora pišu ponajprije o slabim političkim, izbornim rezultatima, ne spominju zadrugarstvo ili širi gospodarski čimbenik, što, dakako, ne znači da ga nisu uzimali u obzir. Podaci o djelovanju zadruga i o Gospodarskoj svezi za Istru mogli su suvremenicima biti dostupni preko Naše sloge. U trenutku kad Obzorovi dopisnici pišu problem zaduženosti seljaštva postoji i on je izražen, ali djelovanje tinjanske posujilnice i drugih zadružnih organizacija vodio je prema slabljenju i ublažavanju problema zaduženosti. Jedan već spomenuti podatak što ga je navela Naša sloga može biti karakterističan. Narodno glasilo ističe da se motovunski posjednik Antonio Corazza obraćao izbornicima u tinjanskoj općini, onima „koji su mu jednom dužni bili, piše zatvorena pisma, kojimi ih pozivlje, da glasuju za talijanašku stranku." U pozadini onih koji su bili ,jednom dužni" motovunskom posjedniku morale su stajati zadružne organizacije. $S$ druge strane, postojeća zaduženost seljaka morala je utjecati i na to da su iz njegovih redova dolazili glasovi za protivnike Narodne stranke u Tinjanu.

Svakako da treba imati u vidu međusobno sukobljavanje hrvatskih pojedinaca koje dopisnici ističu. Ali, sukobi u povodu nekih izbora, kao sukobi među općinarima u Tinjanu, mogu biti samo moment u promatranju slabljenja pozicija nacionalnog pokreta, nikako ne i njegova propadanja, nikako ne i propadanja hrvatstva u najširem smislu te riječi - gospodarskom, kulturnom te političkom. Dopisnici $O b$ zora ističu ponajprije izborne rezultate. Optužuje se Političko društvo za Hrvate i Slovence u Istri za pasivnost i nedjelotvornost. Dopisnik Danilo ogorčen je Političkim društvom, jer je, piše, dopustilo uključivanje Talijana i pristalica Ivana Krstića u tinjanske prilike. Ali Krstićeva aktivnost - koju su potpomagali talijanski liberali 
- u Istri traje od kraja XIX. stoljeća, što dopisnik Obzora ima u vidu. Borba hrvatskih narodnjaka protiv pokreta Ivana Krstića već je trajala, bila je u tijeku. Narodno vodstvo uložilo je mnogo rada i energije kako bi se suzbila opasnost. Ivan Krstić umro je 1906. u riječkoj umobolnici. Borba narodnjaka protiv pokreta Ivana Krstića odvijala se istodobno kako se odvijala i izgradnja političke organizacije istarskih narodnjaka te izgradnja gospodarske organizacije nacionalnog pokreta, istodobno kad se odvijao i proces razvoja raznih kulturnih organizacija.

Kritičnost Obzorovih dopisnika proizlazi iz njihova nezadovoljstva načinom rada i djelovanja vodstva nacionalnog pokreta, a povod reagiranju bili su im općinski izbori u Tinjanu. Njihov je pesimizam razumljiv jer izražavaju bojazan od mogućeg gubitka hrvatskog utjecaja, ali se pesimistične pretpostavke dopisnika ne ostvaruju. Time njihovo pisanje odražava i poprima karakter određenog velikog povijesnog trenutka, kad pišu, kad su pod utjecajem Narodnog pokreta u Banovini nastupili kritički prema vodstvu pokreta u Istri i zahtijevali promjene u načinu djelovanja, kad su posrijedi bili ciljevi nacionalnog pokreta. I u Supilovu Novom listu mogu se konstatirati dopisnici koji su spočitavali djelovanje vodstva pokreta pozivajući se pritom otvoreno na skupštinski pokret u Banskoj Hrvatskoj koji je radikalizirao njihove stavove i promišljanja kad su bili u pitanju zahtjevi za ostvarenje prava Hrvata i Slovenaca u Istri.

Istarski su nacionalni prvaci djelovali čitav niz godina, $\mathrm{i}$ to osloncem i pozivanjem na postojeće zakonodavstvo. Istarski nacionalni voditelji, polazeći od iskustva dugogodišnje decenijske borbe s talijanskim liberalima koji im u autonomnim zemaljskim tijelima nisu priznavali ranopravnost, svoje zahtjeve upućuju vlastima pozivajući se na temeljne državne zakone. Pozivanje na legitimnost, već je spomenuto, bit će kontinuitet $\mathrm{u}$ djelovanju istarskih narodnjaka. Bio je to sustavan i uporan rad ne samo u pravno-političkoj sferi nego i u gospodarskom i kulturno-prosvjetnom smjeru, ali i u pogledu religijskih pitanja, kao što je bio problem uporabe glagoljice i staroslavenskog jezika u bogoslužju. No - i to je istaknuto - rad nije uvijek morao donositi rezultate. Pozivajući se na legitimnost, istarski narodnjaci teško su ostvarivali svoje zahtjeve jer je kurijalni izborni sustav pogodovao prevlasti imućnijih, veleposjedničkih i građanskih slojeva, a tu su talijanski nacionalni liberali, kao predstavnici tih slojeva u Istri, bili u prednosti.

\section{Nakon izbora}

Novo tinjansko općinsko zastupstvo konstituirano je 18. svibnja 1903. Za načelnika je izabran Vjenceslav/Venceslav Križmanić, a za odbornike Antun Prelac, Marko Mofrdin-Franković, Frane Bratulić, Ivan Orlich, Feliks/Felice Giorgis, Ivan/ Ive Rajko. Križmanić tom prilikom izjavljuje „da se smatra i jest istarski Hrvat, te da kao takav uzdržavati će hrvatski jezik uredovnim kao do sada, da će nastojat udovoljit opravdanim zahtjevom obćinara bez razlike stranke i narodnosti, dočim da će se 
pokoravati naredbam upravnih oblasti i zemaljskog odbora". ${ }^{85}$ Naša sloga navodi da bi se njegove riječi „,mogle uzeti za dobre, ali skoro će nam budućnost pokazati, hoće li tim riečima sliediti i čini”. Nastavlja narodno glasilo: „Mi ga već sada opominjemo, da se jedan od njegovih doglavnika hvalio, da novoizabrani načelnik će i onako najviše bit za svojim poslom u Kranjskoj, pak da će se on kao njegov zamjenk skrbit za potalijančenje ureda. Srećom taj doglavnik je ostao malko ponazada, te za sada mu još nije sudjeno, da bude zamjenikom, akoprem se je htio kao takav ugnjetavati jur kod predaje ureda." 86

Naša sloga nastavlja pratiti zbivanja u Tinjanu. Prati djelovanje nove općinske uprave na čelu s novim načelnikom. Dopisnici su nezadovoljni novim načelnikom i novom upravom predbacujući kako se općina vodi u talijanskom duhu. U tom smislu iz pera dopisnika istaknut je općinski tajnik Antonio Depiera ${ }^{87}$ Osim toga, novi je načelnik podignuo sudsku tužbu protiv Ivana Defara, ali taj spor nije dobio. Naša sloga ističe da je Venceslava Križmanića u sudskom postupku zastupao odvjetnik Costantino Costantini. ${ }^{88}$ Ovaj je bio prvak talijanskih liberala iz Pazina. ${ }^{89}$

Nisam uspio utvrditi kojeg je odvjetnika imenovalo općinsko zastupstvo za obavljanje pravnih općinskih poslova i je li ga uopće imenovalo.

I Narodni list izražava nezadovoljstvo novim općinskim načelnikom te se kritički prema njemu odnosio. Po onome kako piše jedan dopisnik, načelnik je znao da

85 „Pazinski kotar: Konštituiranje novog zastupstva u Tinjanu.“, Naša sloga, Pula, 21. svibnja 1903.; B. Milanović, Hrvatski narodni preporod u Istri, II, 182, piše da su Ivan Orlich, Felice Giorgis, Ive Rajko, bili veliki protivnici Hrvata.

86

87 „Pazinski kotar: Rieči i čini.“, Naša sloga, Pula, 25. lipnja 1903.; „Pazinski kotar: Obćinskim tajnikom u Tinjanu. “, Naša sloga, Pula, 27. kolovoza 1903.; „Pazinski kotar: Tinjanski načelnik opet odsudjen.”, Naša sloga, Pula, 26. svibnja 1904.; „Pazinski kotar: Hrvatstvo tinjanskog načelnika.", Naša sloga, Pula, 30. lipnja 1904.; „Pazinski kotar: Iz obćine Tinjana.“, Naša sloga, Pula, 9. prosinca 1904.

V. Križmanić podigao je tužbu pred C. kr. kotarskim sudom u Pazinu protiv I. Defara i skupine rodoljuba jer su pjevali pjesmu „Oj Hrvati jošte živi“ s poznatim navodom: „Proklet bio izdajica svake domovine“. Tom se pjesmom Križmanić našao uvrijeđen, premda je on, kako piše dopisnik Naše sloge, "sto i sto puta pjevao i sam tu pjesmu, dok je bio naš, i dok je mislio, ćutio i radio kako to čine svi pošteni Hrvati one obćine“. Dopisniku nije jasno zašto se načelnik našao uvrijeđen, jer je pjesma uperena općenito protiv izdajica svake domovine. Križmanić, piše dopisnik, uvijek tvrdi kako „on nije izdajica, da je on uvjek onaj stari Vence, koji se je prije 5-6 godina borio u naših redovih, čemu se dakle ide sada na naše pjevače srditi radi pjesme, koja mu bijaše još pred koju godinu toli mila i draga“. Prije rasprave 19. travnja 1904., pozvao je sudac Defara „(pošto je kod njega već prije bio načelnik) te mu kazao da li je pripravan dati načelniku ruku pomirnicu, našto je g. Defar odlučno izjavio, da mu nedaje ruke, neka se pravda vrši. Premda se je i načelnik oko njega laskao, ipak Defar nepopusti te smo stalni, da bi bio radje platio globu ili pošao u tamnicu nego li podao ruku nekadanjemu prijatelju istomišljeniku i suboriocu. Kad je načelnik uvidio, da nemože ni sudac ni on sam ništa opraviti kod Defara uztegnu obtužbu te se obvezao platiti parbene troškove i podariti 'Djačkomu podpornomu družtvu u Pazinu' 20 K". "Pazinski kotar: Iz Tinjana pišu nam 1. o. mj.“, Naša sloga, Pula, 11. svibnja 1904.

Na godišnjoj skupštini Istarskog političkog društva - Società Politica Istriana - održanoj u Piranu 7. rujna 1902., Costantini je izabran za jednog od dvoje potpredsjednika. „Il Congresso della Società politica istriana a Pirano", L'Istria, Parenzo, 13. settembre 1902. 
postoji nezadovoljstvo njime u općini. Ujedno dopisnikovo pisanje može poslužiti i kao pokazatelj raspoloženja novog načelnika te kao pokazatelj političkih napetosti u općini. Tako se načelnik „tuži va podeštarije”, odnosno pritužuje u općinskom glavarstvu, kako ga ljudi ne poštuju, „pa ga svakim ruglom nabacivaju u javnosti, da ga na ruglo svietu predstavljaju, da mu čine demonštracije, da pred njim kašlju i čak da mu roge pokazuju, da neće da ga priznaju za načelnika, da druge tako upućuju", zatim da ga ne pozdrave niti mu uzvrate pozdrav, „kao da je on njihov rob, koji bi se morao njima klanjati". ${ }^{90}$ Međutim, načelnik nastupa i posve drugačije, hvali se „va oštarije”, odnosno hvali se u gostionici na sljedeći način: „Ja načelnik Vence sam dobar čovjek, sve pretrpim, poštujem sve i svakoga, ja imam kao načelnik prava uživati čast i poštovanje kako nas i sv. Crkva uči. Ja, kako vidite, se fino, gospodski nosim, kurim najfinije španjolete, ne morem već uživati kmetske hrane. Kad nisu ni poli Langhamera va Pazine znali pripraviti za mene kako treba, sam se ustal od stola i sam šal ća; ja ništo valjam. Vozim se na kolu altrochè stari podstat i preko Drage na Ježenj. Ja šfidam svakoga na kolu. Sada vidite moj dekret s bulom kada sam imenovan za agenta od banke 'Universal', i ću imati 1200 for. plaće na leto. A borbe, da ne poznaju moju glavu, me ne bi bili za podeštata i za agenta storili. Ipak sa svim tim, oštriga bejata (udari nogom u pod) ne te, da me poštuju. Niš zato, ne te oni od hrvatskog partida, zač sam jim jih dosti zafrigal, ali oni pasje vire, ke smo s talijanskimi beči mnogo puta sa bakalarom najeli i vinom napili, zač me pak oni ne poštuju?" Dopisnik nakraju ogorčeno piše da će izaći na vidjelo sve spletke novog načelnika, „te ćemo i mi nastojati, da ga sviet pozna i znade, što je sve učinil, da nas predade Talijan". ${ }^{11}$

Kao pokazatelj nastupanja i djelovanja načelnika Venceslava Križmanića može poslužiti i jedno njegovo pismo. Hrvatsko-slovenska narodna stranka, odnosno Političko društvo za Hrvate i Slovence u Istri, organizira 1906. skupštine koje su bile potpora provođenju nove izborne reforme za bečki parlament, reforme kojom je trebalo državne izbore provesti na temelju općeg izbornog prava. Načelnik piše 23. svibnja 1906. C. kr. kotarskom glavarstvu u Pazinu da se 27. svibnja treba održati tabor na otvorenom, baš pod „Ladonjami” u Tinjanu. Pučanstvo je, kaže, uznemireno i većina je protivna tomu. Smatra da se tabor održava zbog skorih općinskih izbora. Načelnik izražava bojazan da će izbiti tučnjava i tko zna kakve još neprilike. Zato, dodaje, neće moći odgovarati za javni red i sigurnost u slučaju njegova održavanja. Ako se tabor treba održati, neka se Kotarsko glavarstvo pobrine za sigurnost. Pismo ukazuje na postojeće političke napetosti u tinjanskoj općini. Kotarsko poglavarstvo odobrilo je Političkom društvu održavanje javnog sastanka na otvorenom 27. svib-

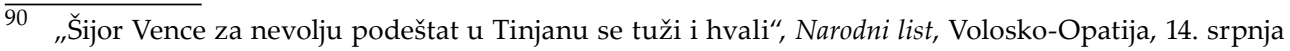
1904.

Na istome mjestu.
} 
nja, s raspravnim predmetom: „izborna preosnova”..$^{92}$ Nisam uspio utvrditi slijed mogućeg zbivanja u vezi s odobrenom skupštinom.

Godine 1907. ponovno je za načelnika izabran V. Križmanić, a u smislu kasnijih dogovora između hrvatsko-slovenskih i talijanskih predstavnika, dogovora iz 1909., odluke o odgađanju općinskih izbora na šest godina, bili su to posljednji općinski izbori u Tinjanu pred Prvi svjetski rat. ${ }^{93}$

Potrebno se osvrnuti na osobu Šime Defara. Podaci već navedeni o njemu upućuju na agilnu i marljivu osobu. Bio je izabran - kao i drugi pripadnici narodnjačkih obitelji središnje Istre - u vodstvo Gospodarskog društva u Pazinu utemeljenog 1900. kao zadruga s ograničenim jamstvom. ${ }^{94}$ Š. Defar naveden je na Popisu članova Političkog društva za Hrvate i Slovence u Istri. Isto je tako bio jedan od izabranih zamjenika odbornika Političkog društva. ${ }^{95}$ Defar je bio posjednik i trgovac, bavio se vinogradarstvom, upućivao je vino carskoj kući u Beč. ${ }^{96}$ Trgovinom vina nastavio se baviti i nakon općinskih izbora u Tinjanu 1903. Otvorio je u Tinjanu „mješovitu trgovinu”, da bi pritom dopisnik Naše sloge preporučio bivšeg načelnika ,jer dok nebudemo imali svojih samostalnih i poštenih trgovaca”, uvijek ćemo biti ovisni „od krnjelsko-talijanskih pijavica". ${ }^{97}$ Kao dugogodišnji predsjednik Cestovnog odbora Kotara Pazin, Defar je zaslužan za uvođenje autobusne linije Pazin - Tinjan - Poreč. Prva vožnja od Pazina do Poreča obavljena je 3. listopada $1908 .{ }^{98}$ Kao predsjednik Cestovnog odbora zalagao se 1911. za uspostavu telefonske linije Pazin - Lindar - Gračišće - Pićan. ${ }^{99}$ Bio je 1909./1910. odbornik Katoličkoga potpornog društva Obrana. ${ }^{100}$

92 DAP, KPP, Udruženja, 1906., kutija 101.

93 Pitanje formiranja i podjele istarskih općina, pitanje preuređenja općina, u austrijskom razdoblju druge polovice XIX. i početkom XX. stoljeća stalno je aktualno. Ujedno je to i jedno pitanje koje se pokreće inauguriranom politikom narodnog mira u Markgrofoviji Istri od strane vlasti u Beču, nakon sklopljenog sporazuma između predstavnika Hrvatsko-slovenske narodne stranke i predstavnika Talijanske liberalne stranke o novoj zemaljskoj izbornoj reformi donesenoj 1908. Dne 31. srpnja 1909. sklopljen je sporazum između hrvatsko-slovenskih predstavnika i talijanskih predstavnika u Istarskom saboru, o odgodi općinskih izbora na šest godina sve dok traju pregovori o novom preuređenju općina, sve dok se ne donese zakon o novoj arondaciji i reorganizaciji općina. Na zasjedanju Sabora 16. i 17. rujna 1909. izabrana je Komisija za nacionalni kompromis koja će najviše raspravljati o pitanju nove podjele općina i razgraničenja općina, jezičnoj ravnopravnosti te zemaljskom proračunu. O toj problematici: Vjekoslav Spinčić, "Die Lage in Istrien“, Slavisches Tagblatt, Wien, 8. november 1910; Un anno di trattative per il compromesso nazionale in Istria. Relazione dei membri italiani della Giunta provinciale e della Commissione al compromesso, Parenzo, 1910., 10-63; D. Šepić, „Politika 'narodnog mira' u Istri 1908.-1913.“, 89-121; B. Milanović, Hrvatski narodni preporod u Istri, II, 148-153, 182; I. Beuc, Istarske studije, 43-138; A. Ara, 290-328.

94 Ž. Klaić, „Prilog proučavanju hrvatskih kreditnih zadruga“, 243, 245-246.

95 Vidjeti bilješku 77.

96 E. Depiera, H. Defar, 75.

97 „Pazinski kotar: Iz Tinjana.”, Naša sloga, Pula, 15. listopada 1903.

98 E. Depiera, H. Defar, 104.

99 Josip Fabris, Lindar. Sjećanja, zapisi, dokumenti o Lindaru dvadesetog stoljeća, Pula, 2002., 53-55.

100 Mladenka Hammer, „Članovi uprave Hrvatske čitaonice i drugih hrvatskih društava u Pazinu na 


\section{Epilog}

Političke suprotnosti i razmimoilaženja u Općini Tinjan na početku XX. stoljeća oko izbora općinskog zastupstva imat će odjeka u posve novim povijesnim prilikama, i to u vrijeme socijalističke Jugoslavije. Bili su to odjeci potekli od nasljednika nekadašnjih sudionika zbivanja, ali su se javili i vremešni pojedinci koji su svojim potpisima htjeli posvjedočiti nekadašnja događanja. Dopisnik se 1962., u Glasu Istre, u svojim sjećanjima osvrće na općinske izbore 1903. Svakako da je njegov osvrt te godine dobio poticaj zbog obilježavanja stogodišnice hrvatskoga narodnog preporoda u Istri. Dopisnik je apostrofirao Venceslava Križmanića kao protivnika istarskih narodnjaka, kao čovjeka koji je radio za protivnu talijansku stranu: „Nakon pobjede talijanaša, za predsjednika općine izabran je neki Vjenceslav Križmanić iz Ježenja, koji je poslije dvije ili tri godine, kada je uvidio koliko je bijedno biti izdajica svoga naroda, napustio predsjedničko mjesto, rasprodao svoje imanje i nastanio se u Puli, gdje ga ljudi nisu poznavali." ${ }^{101}$ Dopisnik ne precizira odlazak Venceslava Križmanića u Pulu. Vrijeme odlaska u Pulu precizira svojim dopisom sin Venceslava Križmanića i pritom odbacuje navod da je nekadašnji načelnik bio „izdajica svoga naroda". Piše da je Križmanić prodao imanje zbog dugova seljaka prema njemu. Platio je dugove, oprostio dugovanja seljaka, pa je od kreditnog zavoda u Poreču dobio zajam i preselio se 1910. u Pulu, gdje je na Kaštanjeru kupio kuću. U nekom smislu može se iščitati da je Križmanićev sin bio ogorčen za njega spornim navodom i zbog toga što je izrečen u tadašnjoj socijalističkoj Jugoslaviji o njegovu ocu, o čovjeku koji je stradao za vrijeme Svjetskog rata, kad su ga austro-ugarske vlasti protjerale u logor u Lajbnicu, gdje je zimi 1915. umro u teškim uvjetima u svojoj 42. godini života. ${ }^{102}$ Premda tematika dopisa prelazi okvir ovog priloga, koji se odnosi prije svega na tematiku općinskih izbora u Tinjanu na početku XX. stoljeća, neki podaci koji se odnose na to vrijeme mogu se uzeti u obzir. Dopisnik navodi da je Venceslav Križmanić na prijelazu iz XIX. u XX. stoljeće bio nadaleko poznat kao najnapredniji domaćin u svojem selu. Uvodio je nove metode rada u obradi njiva i vinograda. Prezidao je i modernizirao kuću, u kojoj je odvojio kuhinju od blagovaonice i spavaćih soba, uveo pod, velike prozore, zahod i odvojio štalu, što tada nije bilo uobičajeno u istarskim selima. Ti podaci sami po sebi ne bi trebali biti dvojbeni

kraju 19. i početkom 20. stoljeća (Popis)“, Hrvatska čitaonica u Pazinu, Pazin, 1999., 304.

101 B. Oplanić, „Sjećanja jednog aktiviste istarskog narodnog preporoda. Izbori u Tinjanu 1903. godine.", Glas Istre, Pula, 28. rujna 1962.

102 Uspit o stradanju stanovništva Istre tijekom Prvog svjetskog rata, o evakuiranom stanovništvu u razne dijelove Monarhije: Mate Balota, Puna je Pula, Zagreb 1960., 127-133, 155-156, 162-187; Davor Mandić, „Pulski Hrvatski list (1915.-1918) - zapisi o 'evakuircima' s područja Pomorske utvrde Pula“, Časopis za suvremenu povijest, 42, 3, 2010., 779-820; Andrej Bader, Zaboravljeni egzodus 1915.-1918., Ližnjan, 2011., 38-249; Mira Kolar-Dimitrijević, „Zbrinjavanje gladne istarske djece tijekom Prvoga svjetskog rata u Križevcima i okolici“, Cris, VIII, 1, 2006., 14-25. 
- upućuju na imućnijeg pojedinca - ali poznata je činjenica da već tada u Istri postoje srednji zemljišni posjednici, imućni seljaci, kao i u središnjem dijelu istarskog poluotoka - na Pazinštini - a to su bili pripadnici istaknutih istarskih narodnjačkih obitelji koji su potpomagali rad hrvatskoga nacionalnog vodstva, na čiji su se rad na terenu hrvatski prvaci i oslanjali. Među članovima prvog Upravnog odbora Gospodarskog društva u Pazinu, kao i među članovima Političkog društva koji su navedeni kao posjednici, treba tražiti srednje zemljišne posjednike. Kad je riječ o njima, na Tinjanštini u obzir treba uzimati braću Defar. ${ }^{103}$ Dopisnik dalje navodi i to da je njegov otac bio pravi narodnjak i rodoljub, koji je u svojoj kući samoinicijativno i o svojem trošku osnovao javnu hrvatsku čitaonicu.$^{104}$ Međutim, Venceslav Križmanić, dok je još bio povezan s istarskim narodnjacima, mogao je biti jedan od onih koji su provodili akciju utemeljenja čitaonice, ne jedini pokretač akcije.

Uslijedilo je reagiranje 27 potpisnika s Tinjanštine rođenih u vremenu 1873. 1899. Između ostalog, naglašavaju da su protivnici istarskih narodnjaka 1903. pobijedili glasovima zaduženih, odnosno zavisnih hrvatskih seljaka, zavedenih od Talijana, te da je nova uprava vodila cjelokupnu administraciju općine na talijanskom jeziku. ${ }^{105} \mathrm{U}$ sadržaju tog dopisa, kao i u sadržaju prvog dopisa Glasu Istre, ne spominju se braća Defar.

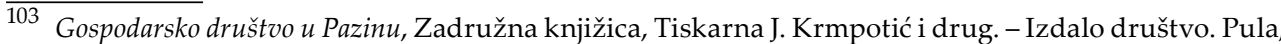
1900., 2-4. Jedan zadružni udio iznosio je 100 kruna; I. Beuc, Istarske studije, 157-161, 184-189, 214-219, 239-244, 261-263, 285-288, 304; Ž. Klaić, „Nacionalni pokret istarskih Hrvata i Slovenaca na prijelomu XIX. u XX.", 53-58.

Dopisnik, između ostalog, o svojem ocu navodi: „On je kao prvi u Istri o svom trošku na svom imanju izgradio streljanu, nabavio top i organizirao obranu od tuče $u$ jeku najvećeg praznovjerja. Zaduživši se na imanje izgradio je oko 1900. god. u Tinjanu moderan mlin i stupu na plinski pogon, tada jedine u cijeloj općini, gdje se dotad tucalo žito, većinom kukuruz za kruh i palentu, glavnu hranu u tadanjoj Istri, u kamenim posudama ili mljelo ručno kao u kameno doba. U mlinu je sam radio sa svojima uz jednog stručnjaka, radilo se besprekidno danonoćno, jer je navala seljaka iz obližnjih i udaljenih mjesta bila neopisivo velika. Zbog njegovih uspjeha nisu zavidnici mogli spavati, pa su mu pakostili na sve moguće načine i stvarali neopisive teškoće protiv kojih se on borio svim žarom svog rodoljublja. Za njegovu i nesreću naroda zaredalo je zatim niz nerodnih godina $\mathrm{i}$ zavladala glad, česti gost Istre. Tada je on uspio nabaviti na kredit veće količine kukuruza i izdavao ga onima koji ga nisu mogli platiti na dug, koji nije nikad naplaćen. Tada su seljaci u znak priznanja i povjerenja, kao najsposobnijeg i najvrijednijeg građanina u općini, izabrali za predsjednika svoje općine u Tinjanu. Nisu njega izabrali nikakvi Talijani ni talijanaši već pravi hrvatski seljaci, koje pisac B. O. u svom članku naziva talijanašima, što mu jedino iredentisti u Italiji neće zamjeriti. Ni kao predsjednik općine Križmanić nije mogao platiti dugove, a ni seljaci zbog slabih godina nisu mogli podmiriti svoja dugovanja prema njemu.“ Milivoj Križmanić, „Ispravak i dopuna napisa 'Izbori u Tinjenu 1903. godine'. Tko je bio Venceslav Križmanić.", Glas Istre, Pula, 19. listopada 1962. Bez obzira na to što dopisnik s odobravanjem promatra djelovanje Venceslava Križmanića i ima afirmativan odnos prema njegovu djelovanju, pisanje očito upućuje na diferencijaciju unutar hrvatskih redova u općini na početku XX. stoljeća, a u koja su se politička previranja i sukobljavanja lako mogli uključiti talijanski liberali ili pobornici istrijanskog pokreta podržavajući jednu od sukobljenih strana kako bi širili i jačali pozicije u općini i oslabili pozicije istarskih narodnjaka.

105 „Izjava grupe mještana Tinjanštine o izboru u Tinjanu 1903. godine“, Glas Istre, Pula, 9. studenoga 1962. 
Poslije izjave mještana Tinjanštine, objavljena je napomena redakcije Glasa Istre. U njoj stoji da je zavođenje nesvjesnih i zaduženih hrvatskh seljaka, pritisak na siromašno i obespravljeno istarsko seljaštvo, u periodu narodnog preporoda nanosilo nepopravljivu štetu hrvatstvu Istre. Ističe se u napomeni da navedeni podaci govore o nesretnim prilikama i teškom životu našeg naroda u Istri, bez namjere da se bilo koga vrijeđa, a zna se i to da potomci mogu pretrpjeti štetu, ali u socijalističkoj zajednici ne snose moralnu odgovornost za postupak svojih predaka. ${ }^{106}$

Uvažavajući tragičnost Venceslava Križmanića i njegove obitelji u vrijeme Prvoga svjetskog rata - kao i nakon rata, kad će se njegova djeca naći u emigraciji - ipak je teško ne prihvatiti ocjenu da se u vrijeme političkih previranja na početku XX. stoljeća u Općini Tinjan, u vrijeme općinskih izbora kao i nakon njih, on našao pod utjecajem talijanskih liberala i pokreta Ivana Krstića.

\author{
Željko Klaić \\ Croatian Press and Municipal Elections in Tinjan at the \\ Beginning of the $20^{\text {th }}$ Century
}

Summary

At the beginning of the $20^{\text {th }}$ century, the municipality of Tinjan was one of the 54 local, or rather regional municipalities in the county of Istria. Towards the end of the $19^{\text {th }}$ century, Croatian-Slovene Populist Party reinforced its position in the municipality of Tinjan. The Party was winning municipal elections even before 1887. As of this year, the Party was continually winning the elections. It won them in all three constituencies; due to the claim submitted by the Italian side, however, the new council was not constituted before 8 August 1888. Sime Defar, leader of Croatian populists in the municipality of Tinjan, was then elected mayor. Again, the Populist Party won the 1891 elections in all three constituencies; the same situation was repeated in the years 1895 and 1899. Šime Defar was every time elected mayor. He was tradesman and landowner, and was connected with other Croatian populists in the central part of Istria and beyond. In 1903, a radical change occurred in the municipality of Tinjan: Defar's party lost the elections, and Venceslav Križmanić was elected mayor. He was repeatedly elected mayor in 1907. In general, Croatian authors explain the defeat of Defar and his Party by Italian propaganda, by peasants being indebted to Italian tradesmen and landowners, by underdeveloped national conscience, and by conflicts in Croatian ranks.

Keywords: Šime Defar; Venceslav Križmanić; Ivan Krstić; Naša sloga; Narodni list; Obzor; municipal elections in Tinjan; Istrian populists; Italian liberals.

Na istome mjestu. 